\title{
SHAKESPEARE E GARRETT
}

\author{
A Roberto F. Giusti \\ FIDELINO DE FIGUEREDO. \\ Professor de Literatura Portuguesa \\ de Faculdade de Fllasofia, Ciencias \\ e Letras.
}

$\begin{array}{ll}\text { Sumário: } & \text { I - Fatos preliminares, em Portugal e Espanha. - } \\ \text { II - Viagens de Garrett e sua iniciação shakespeariana. - } \\ \text { III - Principais influências. - } \\ \text { IV - Um conferencista shakespeariano e outras notícias. - }\end{array}$

Durante os séculos de vigência da estética neo-clássica, fundada na imitação dos autores gregos e latinos, teve de haver modelos para essa imitação, pois o conceito de imitação comporta dois planos opostos: o do imitador e o da pessoa ou coisa imitada, que será o modêlo. E modelos foram todos os autores que atestavam a sabedoria e a experiência da civilização mestra. E houve também orientadores para essa imitação: os teóricos, antigos e modernos, que haviam definido a consciência do absoluto estético, na invenção e na expressão. Supérfluo nomeá-los. Depois da revolução romântica deixou de haver modelos e passou a haver anti-modelos ou exemplos precursores da rebeldia contra a imitação dos antigos, sobretudo contra o acatamento do absoluto condensado nos dois gêneros literários nobres, a tragédia e a epopéia, partes principais do patrimônio espiritual da Antiguidade. Sejam quais forem os conceitos e definições do Romantismo, todos conterão êste comum elemento negativo: independência da imaginação, libertação dela para longe das limitações de estética herdada dos antigos ou deduzida de suas obras. O próprio qualificativo de "romântico" nasceu na Inglaterra, uma das obreiras do Pré-romantismo, para designar o uso da liberdade imaginativa dos romances ou baladas (1). Romances, no sentido de narrativas noveles- 
cas, ou no de baladas tradicionais, foram desconhecidos da Antiguidade, não tiveram teorias reguladoras e só entraram em favor do grande público e da alta crítica após a revolução romântica. Houve no classicismo laivos de romantismo, como através do Romantismo passaram sobrevivências clássicas - isto dando à palavra "classicismo" o sentido de arte de uma classe superior, com seu equilíbrio que desconhece as veleidades individualistas, com sua filosofia da vida bem estabilizada em alicerces inamovíveis, e atribuindo à palavra "romantismo" o significado de crise de tudo isso. Entre os antigos, Ovídio, Catulo, Longus e, em certa medida, o próprio Virgilio, sofreram de alguma adivinhação da psicose romântica. Românticos prematuros foram depois todos os poetas, que em plena era clássica deram relevante lugar ao amor ou anteciparam revelações intuitivas a respeito dêle e passearam a imaginação anelante de liberdade pela história e pela alma dos homens, criando os próprios meios de expressão, à revelia dos teóricos da estética clássica: Petrarca, primeiro cronista da paixão amorosa; Shakespeare, que fêz do teatro um espêlho do perpétuo humano; Lope de Vega e Calderon que acintosamente desconheceram a estética dramática dos antigos e muitas vêzes se sobrepuseram à estrutura social e moral dos seus ambientes históricos. Cada literatura tem seu desenvolvimento histórico e episódico peculiar, e dentro da solidariedade geral - aquela solidariedade que é a base da crítica comparativa ou da literatura comparada. Tem, por isso, seus próprios precursores da liberdade sentimental dos românticos e da fúria individualista. Mas a evolução geral da arte literária ostenta predominantes anti-modelos ou seus geniais mestres da rebeldia. $\mathbf{E}$ dêles o maior foi Shakespeare, que tem em germe tôda a concepção romântica da vida, com o que nela podia sobreviver de clássico ou estável, por ser conquista definitiva na compreensão do homem.

Só a crítica romântica, interpretando com espírito histórico as mudanças gerais do gôsto e da sensibilidade pública, haveria de pôr na sua devida altura a êsses geniais românticos do classicismo. Se a Inglaterra nos deu algumas das fôrças inovadoras do Pré-romantismo, sobretudo o seu medievalismo e o seu popularismo, a crítica alemã, com a sua forte panfilia, havia de ensinar ao mundo o que era a grande originalidade estética e psicológica do teatro de Shakespeare. O professor Gonçalves Lisboa, meu saudoso mestre em anos bem distantes, recordou êsses porfiados e eficientes esforços da alta crítica germânica (V. Shakespeare e a 
sua nacionalização alemã, Lisboa, 1913). Essa alta crítica fêz aquêle teatro o que faria ao vinho do Pôrto a alta gastronomia inglêsa: universalizá-lo.

Portugal teve também seus precursores do Romantismo, o maior dos quais foi o poeta Barbosa du Bocage, não sòmente por alguns traços da sua obra, mas também e principalmente pela sua individualidade e pela maneira como desperdiçou a vida. Foi o criador da boemia literária portuguêsa. E cultivou com devoção a fraternidade espiritual com o grande Camões - que junta às suas grandezas a de adivinhar experimentalmente ou em "vivência", como se prefere dizer agora, atitudes românticas em pleno classicismo italianizante. Camões lírico segue a esteira de Petrarca, só cuida do seu amor individual, acompanha, instante a instante, as alterações do seu "plusus amatorius" e conta-nos as efemérides miúdas e singularíssimas da sua paixão. Esse estado de total projeção no ser amado é ortodoxamente romântico; o que dêle se distigue é a forma de expressão e o conceito de beleza e a amplitude das coisas dêsse amor que poderiam confessar-se em versos. E na epopéia, tomou a forma clássica, homérica e virgiliana, mas encheu-a românticamente de matéria nova e exótica, tomou o heroísmo na acepção de peregrinação pelos mares e pelos continentes, de isolamento ante a natureza em pleno espasmo da primeira posse dos homens brancos. Por isso também, o romantismo português se definiu sob o signo de Camões, com sua nostalgia, sua inadaptação, seus exílios dolorosos, suas ânsias de liberdade. Isto equivale a dizer que só os leitores românticos atingiram a plenitude de compreensão da grandeza do poeta. Barbosa du Bocage e João Xavier de Matos foram camonófilos devotos porque estavam já tocados da moléstia romântica.

A distância de séculos, Camões foi o maior dos nossos pré-românticos, o maior dos nossos anti-modelos; foi o que para tôdas as literaturas o poeta de Romeu e Julieta e do Hamlet. E justamente no espírito e no coração do primeiro dos nossos obreiros do Romantismo, de Garrett, se encontram o culto caseiro de Camões e o culto forasteiro de Shakespeare. A obra de Garrett, com seus sentimentos de devoção shakesperiana repetidamente confessados, é mesmo uma fase importante na carreira do poeta de Warwick através do mundo da língua portuguêsa.

Tanto quanto posso recordar velhas leituras, que me não é dado renovar ou ampliar neste momento, a mais antiga referência de franca 
admiração, em plena vigência do gôsto clássico, a Shakespeare é a de Manuel de Figueiredo, comediógrafo e crítico empenhado justamente na restauração do teatro, sob a égide de uma academia conservadora, a Arcádia Lusitana. Os estilos literários, como os estilos políticos, no último período de sua vida, requintam de intolerância defensiva. Figueiredo recapitulou com agudeza tôda a tecria da comédia antiga, mas numa das suas dissertaçōes críticas tem uma veneta de sinceridade libertadora, para declarar: “ .Os Dramas mais insipidos são os em que se achão mais bem observados os preceitos da Arte. Não vos opprimais, Espiritos grandes, com a multiplicidade de regras, buscai o fim, movei as paixões; mais estimo huma cena dos monstruosos Dramas de Shakespeare, do que os regulares Poemas de. mais fogo tem huma atrevida pincelada de Jordão, do que os correctos contornos de.. " (V. Obras Póstumas de Manuel de Figueiredo, Lisboa, 1804-1810). O que Figueiredo, pobre oficial de secretaria em Lisboa, sequestrado do alto convívio literário, concedia, era em breve retirado pela Marquesa de Alorna, aristocrata muito viajada e convivia pelas côrtes de além pireneus. Tendo estado também na Grã Bretanha, não aprendeu aí a apreciar Shakespeare, que tinha por "doido e grosseiro", extravagância que "só os inglêses aturam" Convém lembrar que em pleno reinado do Pré-romantismo, havendo residido na Alemanha, a Marquesa de Alorna foi devota tradutora da Arte Poética de Horácio e da de Pope. Aquêle êrro não a impediu de escrever êste passo na sua Autobiographies: "Il faut faire le bien, sans s'occuper des fausses interprétations que les méchants savent lui donner. To-be-or not to be is the question - paroles de Shakespeare qu'elle citait souvent pour se soutenir" (V. Inéditos, publ. por Hernani Cidade, Lisboa, 1941). Alguma coisa ficara da leitura do Hamlet, alguma coisa que atestava sua profunda realidade. E quem sabe se aquêles apodos de "doido e grosseiro" só queriam expressar a surpresa que produz a própria realidade doidamente grosseira. Não eram muito outras as opiniōes de Voltaire, anglófilo, e de La Harpe, crítico profissional.

O descobrimento de Shakespeare no continente europeu é lento, estende-se de 1680 a 1800 . Estes foram os limites cronológicos das sábias investigações do Prof. Paul Van Tieghem em La Découverte de Shakespeare sur le continent (Paris, 1937). Tanto pelas épocas, a que se reporta, quanto pela porção de continente sôbre que se exerce a sua pesquisa, França e Alemanha principalmente, o comparatista francês não 
considerou a história literária portuguêsa, em verdade, no período arcádico, muito pequena caixa de ressonância para a voz estentória do gênio de Warwick. A reabilitação ou o reconhecimento pleno de Shakespeare foi obra do Romantismo e, entre nós, teve como agente principal a Almeida Garrett, obreiro inicial da reforma romântica.

Naturalmente, não se deve pensar que, na segunda metade do século XVIII, Shakespeare apenas tivesse dois leitores em Portugal: Manuel de Figueiredo e a Marquesa de Alorna. Quantos mais não terão percorrido os próprios textos, que êles possuiram! O que sucedeu foi que êstes dois foram os únicos ou foram dos poucos leitores que registraram o seu juízo. A vida vive-se com palavras faladas e não escritas. Os documentos são uma pobre estratificação dela. E ainda bem! para que os historiadores e os críticos tenham que fazer.

Em história, silêncio não significa forçosamente desconhecimento; pode também expressar uma hierarquia ou escala de valores na atenção. Também o registro escrito dos sucessos pode enganar. Redondamente se enganaria quem baseasse a sua compreensão das sociedades hodiernas apenas sôbre a imagem, que dela nos pintam os jornais, empenhados na pesquisa do singular, do anormal e do sensacional. $O$ teatro inglês era conhecido dos árcades, mas como um valor exótico, distante do primeiro plano dos apreços. Havia, a dentro do gôsto português, uma luta entre o teatro espanhol e o teatro francês. $E$ êste acabou por vencer. $O$ inglês não tinha beligerância crítica, não a teve na discussão do Marquês de Valença (V. História da Crítica Literária em Portugal, págs. 50-58 da 2a. ed.), nem nas dissertações de Garção, nem na comédia de crítica dramática do mesmo, Teatro novo. Este doutrinador apenas o cita como exemplo da indesejável indisciplina contra a teoria clássica: "Os Ingleses, Nação em que mais se descobre os gênios dos Republicanos antigos, e que no orbe litterário fazem uma grande figura; os Ingleses, digo eu, são os que menos respeitarão esta lei, infringindo-a reiteradas vezes, de que he triste testemunho o seu Catão, e de que talvez os fez gostar aquelle odio, com que sacrificão á sua pertensa liberdade uma testa coroada" (Pág. 299 da ed. de 1778, Obras Poéticas). E claro que havendo notícia dos violadores inglêses da lei que proibia o derramamento de sangue em cena, tê-la-ia também do maior dêles ou do pior dêles, para o seu ponto de vista condenatório das tragédias-açougues. 
Esta tragédia Catão, de que fala Garção, é a de Joseph Addison, de 1713, apologia da liberdade, mais de inspiração estética francêsa do que genuìnamente inglêsa. Foi traduzida por Manuel de Figueiredo e exerceu influência em Portugal, até mesmo sôbre Garrett, no período préromântico. Na lista das obras de Figueiredo - que seu irmão teve de vender a pêso, para libertar os armazens da Imprensa Nacional - essa tradução tem a data de 20 de janeiro de 1779. Também a única tragédia de William Congreve, The Mourning Bride, de 1697, foi traduzida para português por Nicolau Luís e José Antonio Cardoso.

Em Espanha, o processo de descobrimento e assimilação de Shakespeare foi muito diferente. Deu logo de comêço alguns passos seguros. A razão foi que neste país a tradição dramática dos antigos sempre viveu em luta com uma tradição própria. Disso teve certeira intuição Camilo Castelo Branco, ao escrever no seu Curso de Literatura Portuguêsa, em 1876: "Na Espanha era de crer que mais cêdo se restabelecesse o nacionalismo literário, por que aí, como na Inglaterra, prevaleceram sempre os caracteristicos de litteraturas que de si mesmas se alimentavam nas duas grandes personalidades de Shakespeare e Lopo de Vega" (Pág. 273, capítulo sôbre teatro).

Ainda no século XVIII, em franco Pré-romantismo, Ramón de La Cruz tentou a tradução do Hamlet, mas de um falso Hamlet, o da adaptação de Jean François Ducis. Diretamente do inglês e com devoção compreensiva só o traduziu Leandro Fernández Moratín, cujas andanças de funcionário diplomático o levaram para além dos Pireneus, para as proximidades das fontes da nova literatura. A sua versão do Hamlet, publicada em 1798, é o verdadeiro início do culto shakespeariano no mundo espanhol. E é para notar que tal versão e tal "cáos dramático" pudessem convizinhar em sua consciência, lado a lado, à boa paz, com a sua fidelidade a Molière e com a sua francofilia militante. Depois, o Duque de Rivas assume posição análoga à de Garrett, quer no movimento reformador, quer na devoção shakespeariana.

Não se estranhe que em 1772 Ramón de La Cruz adotasse o falso texto de Ducis para a sua tradução do Hamlet. No continente, o nome de Ducis sobrepusera-se ao de Shakespeare. E essa sobreposição transmitiu-se aos países americanos. Ainda em 1842, aqui no Brasil, Domingos José Gonçalves de Magalhães adotava o texto de Ducis para a sua tradução de Othelo, que apresenta como uma "tragédia de Ducis". 0 
que o gênio de Warwick fizera aos seus antecessores no tratamento dos temas, permitira-se Ducis em relação a êle. E com pleno êxito de mediatização. Ducis foi mais corajoso para fazer frente a Napoleão que para arrostar as violências geniais de Shakespeare. Também não há motivo para desconsôlo dos amigos da cultura literária do Brasil, porque em Espanha, já muito adiantado o século XIX, José Maria Quadrado meteu-se a refundir Shakespeare; e Benavente, grande homem de teatro, ainda mais tarde, fêz adaptações dêsse teatro "caótico" no dizer de Leandro Fernández Moratín. E claro que o gênio literário espanhol, eminentemente dramático, aproveitou mais da influência de Shakespeare sôbre a sua criação teatral. Dramaturgos da altura de Echegaray e Benavente atestam a fecundidade de tal influência. No Drama nuevo, de Tamayo y Baus, obra do sub-gênero que designei de "crítica poética" (V. Pyrene, Lisboa, 1935), o próprio Shakespeare é personagem. relevante. E em Troteras y danzaderas, Pérez de Ayala exemplifica a profunda impressão que deixa nas almas humildes. Com tôda essa receptividade maior do gênio dramático espanhol, a obstinação dos prejuízos anti-shakespeareanos e a resistência dos críticos não deixaram de ser alí também muito grandes. Alfonso $\mathrm{Par}$, ilustre erudito catalão, contou isso tudo em obra volumosa, Shakespeare en la Literatura Española, 1935, e com outras investigações constituíu mesmo um departamento especializado, o da carreira do trágico inglês em Espanha. Bem poderiam sugerir êsses estudos, inventariados pelo Prof. Homero Serís no seu prestimoso Manual de Bibliografia de la Literatura Española, empreendimento análogo para o mundo da língua portuguêsa.

O que já não será tão claro é o desintêresse do gênio literário português, eminentemente lírico, pelas grandes obras líricas de Shakespeare. Tudo traduziu e comentou, menos Venus and Adonis e os Sonnets. Dêstes, que me lembre, só se ocupou Fernandes Costa, para salientar a distância entre a sua estrutura métrica e a do soneto de Petrarca (V. Boletim da Academia das Ciências de Lisboa, vol. ).

Ainda se não estudou metòdicamente a história da fortuna de Shakespeare em Portugal - seus episódios concretos, traduções por nomes ilustres, Castilho, Bulhão Pato, Rebelo da Silva, D. Luiz de Portugal, in- 
tepretações por atores de alta inspiração como Anastacio, Brazão, Ferreira: da Silva e Ângela Pinto, e sábias glosas críticas, umas baseadas na literatura erudita dos textos, outras sugeridas por ocasionais passagens por Lisboa de grandes atores estrangeiros, como Rossi, Salvini e Novelli.

Nem algumas conquistas da literatura comparada, que assinalam intemas e formas do mundo shakespeariano, foram ainda incorporadas à fluxos espanhois e portuguêses, diretos e indiretos, entre o patrimônio de história literária de Portugal. Nem sequer as referências aos bons vinhos portuguêses se arquivaram. Ter emborrachado personagens shakespeareanas é um glorioso pergaminho para os vinhedos de Portugal. Nem mesmo se rastreou a presença do poeta na vida e na obra de Garrett, apesar de ser ela bem patente.

Teófilo Braga escreveu muito sôbre Garrett. Os dois volumes de 1904 - 1905, Garrett e o Romantismo e Garrett e os Dramas Românticos, forma uma enciclopédia garretiana, com cêrca de 1.400 páginas. Todavia, só, e muito ràpidamente, alude à sua residência no Condado de Warwick em 1825 e ao seu estudo de Shakespeare (págs. 317 e 481 do primeiro dêstes volumes).

Antonio Arroyo, em 1889, e Joaquim de Araújo, em 1905, escrevendo sôbre o Fr. Luís de Sousa, aludiram também a Shakespeare, ao atribuir linhas de beleza shakespeariana ao caráter e à atuação de Telmo Paes, o escudeiro sebastianista (V. A Estética de "Fr. Luís de Sousa", 44 págs., e o $O$ "Fr. Luís de Sousa", de Garrett, 98 págs. e um apêndice). Mas a êsse palpite impressionista se limitaram. Vagos também, ainda que certeiros, foram os palpites críticos de José Osório de Oliveira em $O$ romance de Garrett, Porto, 1935, - uma biografia novelada, destas que se multiplicaram no intervalo das duas Grandes Guerras, para contentar o gôsto multitudinário. Há alí três referências que são outros tantos acertos. Diz o autor: "O introdutor do Romantismo em Portugal só encontrará a libertação ao tomar contato direto com o mestre dos românticos: Shakespeare. Mas está ainda longe o período em que descobrirá o gênio do teatro" (pág. 38). Refere-se alí aos anos arcádicos e filintistas ou ainda coimbrões da carreira do poeta. Depois, aludindo ao drama Fr. Luís de Sousa, escreve: “Tempo virá em que há-de fazer um drama romântico à maneira de Shakespeare" (Pág. 172). E mais. adiante: "Embora uma única vez, Garrett subirá tão alto como outra. águia: Shakespeare” (Pág. 178). 
Não obstante êste bom instinto, Osório de Oliveira passa ligeiramente, quase com desdém, pela obra que melhor testemunha a influência de Shakespeare sôbre o protagonista da sua biografia novelada: o poema Camões.

Os dois mais recentes estudos de conjunto sôbre o fundador do nosso romantismo nada adiantam a tal respeito. Um dêles, in História da Literatura Portuguêsa Ilustrada dos séculos XIX e XX, Porto, 1942, apenas alude à residência do poeta no Condado de Warwick e às suas leituras inglêsas (pág. 32). O nome de Shakespeare ocorre numa referência à doutrina dramàtica de Garrett (pag. 45), e numa alusão ao contraste entre o historicismo do teatro shakespeareano e o historicismo do teatro garrettiano, contraste documentado com a substância do Hamlet e do Julius Cesar. Isto é exato, mas nada traz para o nosso especial ponto-de-vista. A outra obra, em que também se contém um capítulo de conjunto sôbre Garrett, é a Perspectiva da Literatura Portuguêsa do Seculo $X I X$, dirigida por João Gaspar Simões e ainda em curso de publicação. Nada há nela sôbre êste particular. Também, dada a índole da obra, segundo o pensamento do seu arquiteto, o redator dêsse capítulo não era obrigado a versar êsse pormenor: influência de Shakespeare sôbre Garrett. O caráter perspectivo e memorial da obra exigia a confissão da influência de Garrett e dos outros autores do seculo XIX sôbre outros tantos autores do século XX. (V. o prefácio pelo diretor dela, págs. 9-10). Assim o entendi eu, que não estudei Antero de Quental em si, pròprimente, mas nos seus reflexos sôbre mim. (Ibidem, págs. 549-569).

E fora de dúvida que o autor de Camões e Fr. Luís de Souza é que foi, no romantismo português, o redescobridor de Shakespeare, levando a bom têrmo o que Manuel de Figuereido, com certeira intuição apenas entrevira como vago precursor. E converteu-se com entusiasmo ao novo culto, que vinha implícito na reforma romântica. O filão inglês, que Almeida Garrett representa em nosso romantismo, com sua poesia nostálgica, sua soberania amorosa, seu individualismo estético e até seu popularismo ou folclorismo, tem um laivo shakespeariano. O que poderá ter acontecido é que o poeta português, pouco antes convicto árcade e sempre dominado pelo prestígio da Antiguidade, não atingisse logo a riqueza do novo patrimônio adquirido e que o poderoso enxêrto cultural não tivesse dado todos os seus frutos, que pediam tempo ao tempo. 
A presença de Shakespeare na obra de Garrett assinala-se por duas maneiras diversas: uma superficial, por meio de alusões e reminiscências de leitor devoto, outra profunda, por meio da influência de algumas das grandes criações do poeta de Warwick sôbre obras principais de Garrett. Para atestar a primeira, basta percorrer as páginas de Garrett e assinalar os rastos shakesperianos que se nos forem deparando. Isso farei. Para pôr em relêvo a segunda maneira ou para apontar os casos em que o mundo shakesperiano se tornou fonte de inspiração garrettiana, será necessário adotar um conceito de "fonte literária" diverso do corrente em várias partes.

Crê-se de ordinário que uma fonte literária é um vestígio de leitura, documentável por uma coincidência formal ou estilística, isto é, de palavras e maneiras de dizer. $\mathrm{O}$ crítico de fontes reconstituiria assim as leituras ou a alimentação espiritual do poeta, como quem mostrasse uma digestão em flagrante. Este conceito de fontes tem por detrás um conceito da arte literária muito limitado e retrógrado, mesmo em relação aos antigos. Viam êstes na elaboração da arte uma fúria críadora; vêem êstes críticos, nela, uma paciente recomposição ou guizado de ingredientes por outrem colhidos e acumulados. $O$ poeta seria sobretudo um homem de muita leitura, que de forma nova combinaria as suas reminiscências dos livros, dos quais passariam laivos indisfarçáveis na nova obra, como passam os sabores dos temperos nas iguarias mais requentadas ou transformadas, sob ação do fogo. (Falo da cozinha européia que funde sabores, não da cozinha norte-americana que apenas os justapõe). Em Portugal, o nome clássico entre os militantes dêste conceito de crítica de fontes foi o Dr. José Maria Rodrigues, que nos deixou nas Fontes dos "Lusíadas" um insuperável exemplo de erudição e de esfôrço por achar todos os sabores discrimináveis no sabôr sintético da nossa grande epopéia. Que ingredientes entraram na condimentação dêste prato? Que leituras prévias vieram a constituir êste novo texto ou esta nova expressão de uma velha situação moral? - parece que é êste o problema capital de tão limitada concepção. Assim, desde que o mundo é mundo, a emoção dos que partem a empreendimentos incertos é levar saudades e deixá-las aos que ficam na praia apreensivos sôbre o desfêcho da aventura. Dêste modo, tudo o que se escreveu sôbre essas partidas, é fonte do episódio do Velho Restelo, porque uma constante situação moral evoca palavras constantes. 
Contra êste conceito reagí, também a proposito da obra capital da literatura portuguêsa (2). E agora, em proporções menores, exemplificarei a propósito de Shakespeare e Garrett essa evasão dos estreitos limites da simples análise estilométrica.

A iniciação de Garrett no culto shakespeariano deve ter sido feita em Inglaterra, aonde o poeta foi vêzes várias, como exilado também nalguma comissão política. Antes de tais viagens, eram rigorosamente verdadeiras estas linhas de uma nota da Lírica de João Mínimo: "O meu entusiasmo neste tempo não via no mundo poético senão Horácio e Filinto Elísio" (Pág. 96 da ed. grande de 1904, 1. ${ }^{\circ}$ vol.). E filintista é - espírito dessa obra, ainda que o seu prólogo seja datado já de Birmingham, em Warwickshire.

Aproximava-se de Shakespeare. Efetivamente, apesar daquela declaração de fé horaciana e filintista, e das abundantes epígrafes de autores antigos que antecedem os textos poéticos, Shakespeare já aparece três vêzes entre êles, a última à frente da poesia $O$ exilio, que é datada de Warwickshire, Novembro 1823. Dêle são também as epígrafes que precedem as quatro "cantigas" do poema Adozinda, cuja primeira edição é de Londres, 1828, obra que inicia o filão popularista da carreira literária de Garrett. Estão ali com a mesma intenção que as epígrafes camonianas dos dez cantos de Camões: a condensar e a anunciar o seu caráter dominante. Tais epígrafes, não se thes designando o lugar da obra de Shakespeare, de onde foram extraídas, correram sem revisão e, portanto, com suas incorreções. Numa nova edição crítica ou dirigida por alguém responsável, será necessário apontar a localização delas no grande conjunto, par que tais deslizes sejam corrigidos. Mas esta restituição das epígrafes shakespearianas nas obras de Garrett envolve outro problema, dada a variabilidade dos textos do poeta inglês: por que edição o leu êle? A de Inglaterra seria a mesma que depois repetidamente consultara em Lisboa? Não se trata de restituir textos shakesperianos; trata-se de reconstituir leituras shakesperianas de Garrett - coisa muito diversa. Infelizmente não posso agora utilizar as notícias apuradas pelo meu amigo Ferreira Lima acêrca da livraria de Garrett. Só disponho do inventário do seu espólio literário (3), onde, à pág. 8, encontro a seguinte rubrica: "34) Othelo, Tragédia. Ato primeiro. Cena I. Aut. de 2 págs". 
De 1822, e ainda de Lisboa, é o prefácio da 1a. edição da tragédia Catão, no qual se nota a aspiração do poeta a uma forma dramática nova, que não fôsse inteiramente clássica, nem rebeldemente anti-clássica.

Era uma concepção tìmidamente eclética de romantismo, ainda muito fiel à tradição francesa, a Racine, Voltaire e Crébillon, mas reconhecendo já as contribuições italianas para a revivificação do gênero, e era também, a propósito, um reconhecimento muito tímido da originalidade e da fôrça de Shakespeare: "Todos sabem que o gênero romântico, fitho de Shakespeare, formou uma classe distinta e separada, que, suposto irregular e informe, tem contudo belezas próprias e particulares que só nele se acham" (Pág. 527 da ed. cit. $10^{\circ}$ vol.). O próprio contexto nos leva à convicção de que êstes conceitos de romantismo e de Shakespeare são adquiridos em "cursos de literatura", são de segunda mão. (4) As viagens lhe dariam as justas proporções do gênio de Warwick, já liberto das adaptações desfiguradoras de Ducis.

Há notícias das seguintes viagens de Garrett ao exterior: a primeira em 1823, em resultado do golpe de Estado da Vilafrancada, que aboliu a nossa primeira Constituição liberal e restabeleceu o regime absoluto; a segunda nesse mesmo ano, depois de uma tentativa de regresso à pátria; a terceira em 1828, depois da usurpação do trono pelo Infante D. Miguel, que suprimiu a Carta Constitucional e se proclamou rei absoluto; a quarta em 1832, como secretário de Palmella, que ia a Londres em missão política; finalmente, a quinta e última em 1834, como encarregado de negócios de Portugal na Bélgica.

Foi na segunda emigração que êle, acompanhado da esposa estremecida, de que se havia de separar irrevogàvelmente após a estada em Bruxellas (5), intimou com uma família inglêsa, os Hadley, de Egbaston, pelo que pôde aprofundar a observação da vida britânica e o recebimento da nova sensibilidade romântica. Egbaston está situada no Condado de Warwick, não longe de Etratford-upon-Avon, terra natal de Shakespeare, que naturalmente o poeta exilado visitou vêzes várias. Warwick era por isso, pelas recordações ali colhidas e até pela maior amenidade do clima e suas facilidades de vida, lugar predileto de Garrett. Ali viveu tanto tempo quanto lh'o permitiram as difíceis circunstâncias do exílio. Essa predileção foi oficialmente reconhecida e permitida em 1828 pela Embaixada da Regência (V. Amorim, Memórias biográficas, pág. 475 do vol $1^{\circ}$ ). 
São dêsse tempo as recordações que passam nas Viagens na Minha Terra, principalmente as daquele vivo documento de donjuanismo romântico, a carta final de Carlos a Joaninha. (6). Dêsse exílio, repartido por Inglaterra e França, sairam também as obras iniciadoras do gôsto romântico em Portugal, Camões e $D$. Branca. No primeiro dêstes poemas há reminiscências da sua excursão ao Castello de Dudley, um evocador quadro de ruínas góticas essencialmente romântico. Ele confessou a sua grande impressão num escrito só publicado em 1845, Folhas tiradas do album de um emigrado, e lembrou também como a arquivára em sua obra: "Ainda me estavam todas frescas no coração e no pensamento essas imagens e essas idéias, quando, poucos meses depois, escrevia, no VII canto de Camões, aquele Super flumina Babylonis do meu primeiro desterro. " (Pag. 485, Obras Completas, $10^{\circ}$ vol.). E é de notar como êste poeta português, emigrado de um país ouriçado de castelos roqueiros, qual dêles mais evocador ou mais repassado de história e lenda, só na distante Inglaterra adquire receptividade para êsse mundo poético medieval, sìmbolizado nas ruínas. Por que haviam as ruínas dos castelos inglêses de ser mais impressionantemente evocadores para um português que as da sua própria terra? Porque não eram as ruínas que em si guardavam a impressividade, mas os poetas seus contempladores que em si possuiam ou deixavam de possuir um poder de visão nova. E Garrett só em Inglaterra aprendeu a ver as coisas com olhos românticos. Exatamente o fenômeno da restauração do gôsto dos clássicos: êstes foram sempre os mesmos, sôbre todos os nunca esquecidos durante a Idade Média, como Virgílio, mas só os homens do Renascimento os souberam ler com nova receptividade.

Esses versos iniciais do Canto VII Camões, em que há pessoais sentimentos do exilado Garrett, que por isso êle chamou Super flumina Babylonis do seu primeiro exílio, têm toda a fragrância de coisa bebida em sua própria fonte, a fonte principal da poesia das ruínas:

Eu vi sobre as cumiadas das montanhas

De Albion soberba as torres elevadas

Inda feudais memorias recordando

Dos Britões semi-bárbaros. Errante

Pela terra estrangeira, peregrino

Nas solidóes do exílio, fui sentar-me 
Na barbacã ruinosa dos castelos,

A conversar co'as pedras solitárias,

$\mathrm{E}$ a perguntar às obras da mão do homem

Pelo homem que as ergueu. A alma enlevada

Nos românticos sonhos, procurava

Aureas ficções realizar dos bardos;

Murmurei os tremendos esconjuros

Do Scaldo sabedor; falei aos ecos

Das ruínas a língua consagrada

Dos menestreis; - perfis solenemente

Todo o rito; invoquei firme e sem mêdo

Os gênios misteriosos, as aéreas

Vagas formas da virgem d'alvas roupas

Que, as tranças de ouro penteando ao vento,

Canta as canções dos tempos que passaram

Ao som da harpa invisível que lhe tangem

Os domados espíritos que a servem,

Como o sutil Ariel, por invencível

Encantado feitiço.

Depois, o desenvolvimento do quadro de medievalismo cavalheiresco utilisa as decorações de Walter Scott e sobrepõe-nas mesmo às profundezas do mundo shakespeareano. Sempre se me afigurou que o poeta português, criador de cenários amáveis, sem a emoção violenta que excepcionalmente nos deu em Camões e Fr. Luís de Sousa, mais queria Shakespeare para leitura dileta que para exemplo da concepção amarga da existência. Assim, a influência dêle recebida será mais formal, isto é, de técnica da expressão, do que essencial. Macpherson vem aliar-se a Walter Scott nalguns momentos e carregar as côres da substância herdada de Shakespeare.

\section{III}

No Camões, o poema iniciador do gôsto romântico, é que se confessa com ardor a devoção shakespeareana e se ostenta a primeira grande influência do mundo shakespeareano no nascente mundo garretteano.

No capítulo XV do Canto I, quando nos descreve a chegada de Camōes à pátria, celebra o encanto do crepúsculo vespertino e realça 
êsse valor tìpicamente romântico por meio de reminiscências shakes. pearianas:

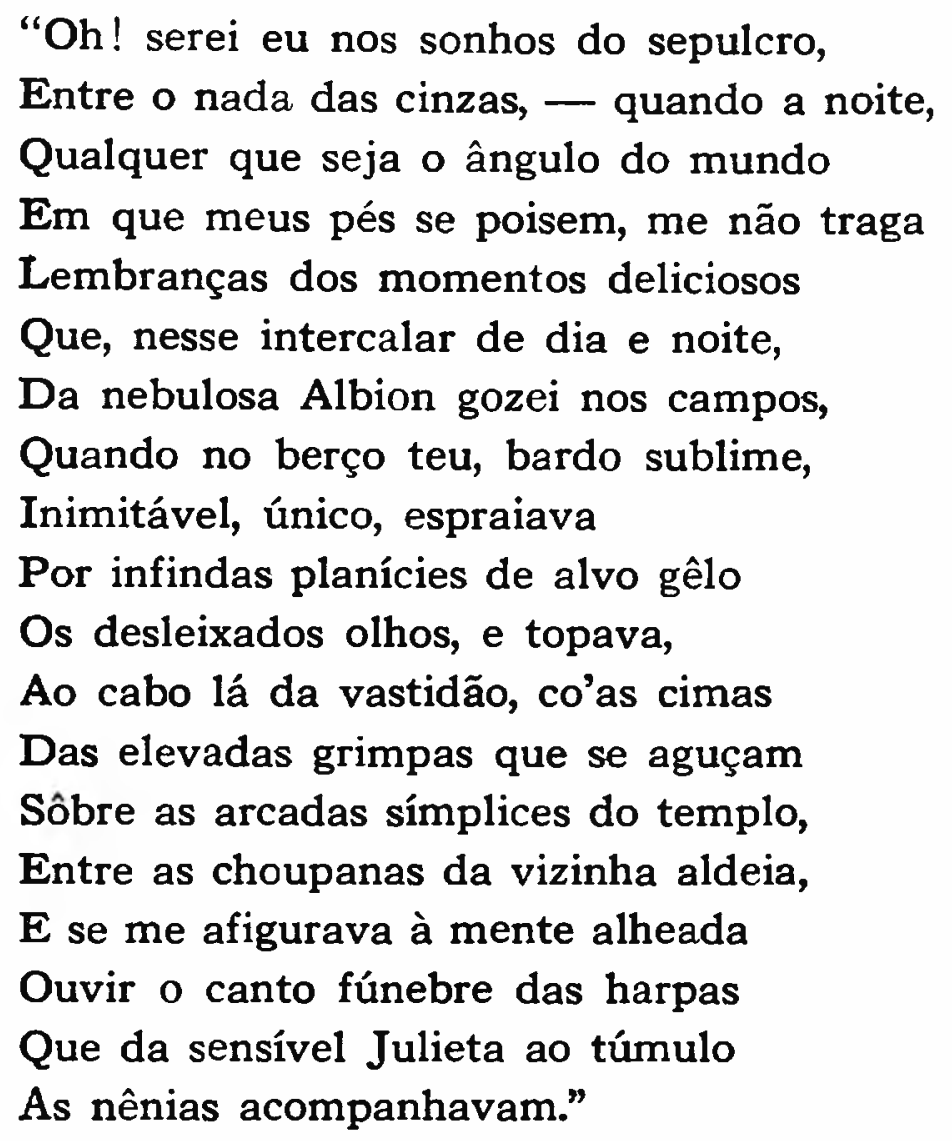

(Pág. 200 da ed. cit., $10^{\circ}$ vol.)

Escrevendo a um amigo íntimo, Duarte Lessa, em 27 de Junho de 1824 , portanto durante a redação do poema, assim the anuncia o conteúdo e caráter dêle: "A obra é um poema em dez cantos, cujo título e assunto é - Camões. Suas aventuras e suas composições formam o mundo histórico; mas os Lusíadas principalmente ocupam a cena. - A ação é a composição dos Lusíadas - e portanto grande parte do meu poema uma análise poética dêle," (Pag. 779 da ed. cit, $2 .^{\circ}$ vol.). E no prólogo da edição de Paris, no ano seguinte, diz a mesma coisa. Ora a verdade é que, no poema, é também ação a história dos contrariados e infelizes amores de Camões. E essa história de amor, como a concebiam os românticos mistizadores da vida do épico, é a parte mais flagrantemente romântica e shakespeariana do poema. O modêlo poético ou literário para tôdas as histórias de amores contrariados pelos ódios familiares era a tragédia Romeu e Julieta, que associa à veemência dêsses 
amores a separação dolorosa, os duelos e a surpresa da morte no único momento de possível ventura pelo regresso do amante perseguido. A visão do caráter de Camões pelo poeta romântico está impregnada de espírito shakespeariano. Luiz de Camões é, no poema de Garret, um Romeu. Mas, como veremos que sucede sempre que o poeta do romantismo português toma elementos expressivos a Shakespeare, êsse Romeu é mais do que um poderoso valor local, paladino da honra de uma família de Verona contra outra da mesma cidadezinha. Camões é um espadachim que deixa a sua Verona para ir devassar mundos novos e cooperar com seu heroismo anônimo na construção e manutenção de um grande império - que de fato êle salva do olvido com sua epopéia. Ser desterrado de Lisboa para o Ribatejo e para Marrocos, e desterrar-se para o Extremo Oriente é pena bem maior que deixar Verona por Mântua. Mas como Romeu, no seu regresso de Mântua, encontra Julieta morta, ou a crê morta em vez de adormecida por um narcótico, assim Camões chega do remoto Oriente a Lisboa no preciso momento para presenciar o funeral de Natércia, para descer á cripta sepulcral e ali, junto do corpo da amada morta, tombar desvanecido pela dor. No romantismo os espadachins eram neuróticos, batiam-se mas também desmaiavam. Esse abuso dos delíquios tem uma explicação estética: era necessário demonstrar a fôrça dominadora da paixão sôbre a vontade e sôbre todos os sentidos. Abuso equivalente praticará o realismo com os sonhos, que revelam os caracteres, libertando a consciência das coações sociais. $\mathbf{E}$ assim os realistas anunciarão o freudismo.

Ou porque os verdadeiros românticos, os da sua hora própria, eram mais obedientes às fulminações da paixão do que os românticos prematuros de Shakespeare, ou porque a essência camoniana do poema se sobrepusesse no ânimo de Garret às reminiscências de Romeu e Julieta, ou sòmente porque uma coisa é uma tragédia e muito outra um poema lírico ou ainda porque as concepções do caráter humano eram muito diversas no século XVI e no XIX - o Camões garrettiano não faz nenhum discurso sôbre a beleza e a morte, na cripta, como Romeu, e reserva o desabafo da sua dor para a canção necrológica do Canto $\mathrm{V}$, tôda motivada na contemplação lacrimosa da grinalda de rosas que se desprendera do ataúde. $O$ camoneanismo do expediente expressivo provinha da evocação das canções autobiográficas de Camões, muito mais românticas do que todos os discursos. 
O ódio familiar do Romeu e Julieta é bilateral, mas no poema de Garrett, tornando-se unilateral, torna-se também mais violento, porque é ódio de uma família poderosa contra um pobre poeta desvalido. Há também a boa aliança de um monge, mas não para proteger amores mortos, só para procurar alguma reparação do destino para o poeta malaventurado. Não terá havido sugestão shakespeareana na criação dêsse tipo, mas, se a tivesse havido, a distância que vai de Frei Lourenço, frade arteiro, herbanário e toxicólogo oculto, a um antigo conquistador da América e, depois da conversão pelo remorso, ardoroso missionário no Oriente, é infinita. Também aqui se verificará o tal engrandecimento compensador da perda de prioridade original.

Onde, porém, se ostenta mais evidente a influência shakespeariana é no Canto III, naquele episódio com que Almeida Garrett resolve a seu modo imaginoso um problema insolúvel da vida de Camões, inexistente ante a verdadeira crítica ou ante o exato conceito de uma epopéia de comunhão cívica: qual o momento ou qual a causa próxima que determinou Camões a compor o seu poema? Garrett românticamente, noutro delíquio, supõe que sob a nave do Mosteiro dos Jerônimos o espectro de D. Manuel I teria aparecido a Camōes, para lhe cometer a tarefa ingente:

— "Jovem ousado,

Grande emprêsa te coube, acerba glória, De que não gozarás! Desgraças cruas Fadam teus dias. Mas a fama ao cabo.

A pátria que foi minha, que amei sempre. Que amo inda agora, gram' serviço aguarda

De ti. Um monumento mais durável

Do que as moles do Egito, erguer-lhe deves.

Pirâmide será por onde os séculos

Hão-de passar de longe e respeitosos.

Galardão, não o esperes. - Fui ingrato

Eu, fui! Ingrato rei, ingrato amigo.

E a quem! - Maiores de meu sangue ainda

Ingratos nascerão. Tu serve a Pátria:

$E$ teu destino celebrar seu nome.

Os homens não são dignos nem de ouví-las, As queixas do infeliz. Segue ao Oriente, 
Salva do esquecimento essas ruínas Que já meus netos de amontoar começam Nos campos, nos alcáceres de glória, Preço de tanto sangue generoso.

Um dia. Em vão perante o excelso tronco Do Eterno me hei prostrado; irrevogável

A sentença fatal tem de cumprir-se Um dia inda virá que, envilecido, Esquecido na Terra, envergonhado O nome português. - Opróbrio, mágua,

Dura pena de crimes! Tábua única Lhe darás tu para salvar-lhe a fama Do naufrágio. Tu só dirás aos séculos, Aos povos, às nações: Ali foi Lísia. Como o encerado rôlo sôbre as águas Unico leva à praia o nome a fama Do perdido baixel. - Parte. Salvá-lo! Salvá-lo, enquanto é tempo! Extinto. Infâmia! Extinto Portugal. Oh dor!.

Este episódio é o núcleo decisivo ou o eixo da ação do poema, como decisivo é o episódio da aparição do espectro do rei da Dinamarca ao principe, no Hamlet, de Shakespeare. Na tragédia inglesa, o espectro reveste exatamente a forma do rei morto, resplandecente na sua armadura de aço, sob a lua, comete-lhe a missão de vingar o seu assassínio; no poema português, o espectro reveste a forma do rei, que personificou o momento supremo das miragens heróicas da India, D. Manuel I, mas disfarça-se ou impersonaliza-se debaixo da legenda que lhe brilha sôbre - coração - Amor da Pátria; e é com essa autoridade que incumbe o joven poeta de salvar do esquecimento o nome da Pátria. Tanto um como outro se confessa réu de pecados e delitos, mas enquanto o primeiro, rigorosamente individualizado em certa personagem que realmente existira em certa data, encarrega o filho de uma tarefa de vingança ou de justiça familiar, quando muito de defesa da dignidade dinástica, o outro, impersonalizando-se ou guindando-se a um geral sentimento, que é uma fôrça moral, o patriotismo, encarrega o poeta de uma alta missáo histórica. A de Hamlet é profundamente humana, mas limitadamente 
familiar e local daquele pequeno ambiente de Elsenor; a de Camões é de alcance mundial, porque celebra e imortaliza uma grande façanha da história da civilização. Portanto, Garrett adotando um expediente expressivo, muito praticado por Shakespeare, a aparição de fantasmas, dáthe um significado muito mais amplo, assim resgatando a falta de prioridade original. Procede como o próprio Camões, no século XVI, ao tomar dos antigos tôda a técnica da composição das epopéias, mas incutindo-lhe matéria nova, de mais transcendente valor humano ou mundial. Shakespeare aprofundou o conhecimento do homem singular; e o romantismo alargou o conhecimento do gênero humano.

Convertendo o seu Camões-Romeu num de tantos heróis obreiros do império do Oriente, associando ao valor abstrato do prestígio poético o interêsse das aventuras e maravilhosas surpresas de mundos exóticos, Almeida Garrett evitou o grande risco de inferiorizar a nossos olhos a figura do poeta - risco menor do que no teatro, mas ainda para temer. (7) Este Camões do poema garrettiano não é sòmente um Romeu, é também um byroniano. $O$ poeta e $\circ$ seu jau, com seus mistérios e ceticismos, com seu individualismo anárquico ou anti-social, são parentes do corsário Conrado, de Lara e outros heróis byronianos - como o é Eurico, enquanto presbítero perdido nas rocas do Calpe. Byron é o pai de tôdas as apologias poéticas do individualismo romântico, acima das leis, como os artistas da Renascença. A grande obra dos românticos era a sua própria vida. Até o ambiente marítimo tem tintas das marinhas de Byron. Mas Garrett fez à poesia do mar de Byron, que era o Mediterrâneo, o mesmo que fêz aos recursos expressivos tomados de Shakespeare: ampliou-lhe o raio. E d'onde vinha essa ampliação? Do toque mágico do velho espírito universal da história portuguêsa. Quando nos pinta o solitário melancólico no momento da sua chegada:

Um só no meio de alegrias tantas

Quase insensível jaz.

e quando nos evoca a tristeza profunda do mar desconhecido:

Longe, por esse azul dos vastos mares,

$\mathrm{Na}$ solidão, melancólica das águas

Ouví gemer a lamentosa Alcione

E com ela gemeu minha saudade. 
retoma atitudes byronianas da sensibilidade, mas adapta-se a motivos maiores, a motivos portuguêses e mais humanos. $O$ mistério do poeta que chega do Oriente é bem mais rico do que o mistério de um corsário mediterrâneo. A sua memória é fiel a êsse gôsto marinheiro do poeta inglês, mas reconhecendo já a estreiteza do seu perímetro, reconhecendo-o implìcitamente, ao evocá-lo numa obra de sorridente bom humor: "Não me lembra que Lord Byron celebrasse nunca o prazer de fumar a bordo. E notável esquecimento no poeta mais embarcadiço, mais marujo que ainda houve, e que até cantou o enjôo, a mais prosáica e nauseante das misérias da vida" (Viagens na Minha Terra, Cap. I).

Neste Camões garrettiano há uma convergência de influxos inglêses: Shakespeare, Byron e Scott. E o curioso é que, logo em 1829, um viajante inglês em Portugal, Kinsey, achava no poema o que êle, inglês instruído nas correntes do tempo, trazia no próprio espírito, Shakespeare, Byron e Scott: "Portugueses throughout, catches the manner of Shakespeare, and sometimes reminds us of the flexibility of Scott, at others of the force of Byron" (Portugal illustrated). Se Kinsey houvesse mencionado também ao bispo Thomas Percy, com as suas Reliques of ancient English Poetry, teria apontado tôdas as grande influências do filão inglês do nosso romantismo, como Garrett o representa.

Estèticamente, o poema $D$. Branca, acêrca da conquista do Algarve pelo rei $\mathbf{D}$. Affonso III, de Portugal, de envolta com um argumento amoroso, é um retrocesso. A consciência da reforma romântica está nêle mais patente, mas faita-lhe a verdadeira inspiração romântica. No Camões, a identidade de situações pessoais entre o poeta do século XVI e o do XIX, e o entusiasmo pelo poema épico, ainda então visto só como bíblia do patriotismo lusitano, produziram acentos profundos da sensibilidade nova. Mas em $D$. Branca, ainda que fôsse composta no ano imediato, como que recrudesce a influência filintista; e o irracional da paixão é substituído pelo irracional fantástico de bruxedos e magias.

O choque das civilizações cristã e árabe, na península ibérica, sempre constituíu uma zona fronteiriça de fantasias e encantamentos, não sòmente um fator de causalidade para coisas peculiares, estranhamente peculiares à península, mas também um refúgio para o inverosímil, para o proibido, para o ilógico, para quanto era impossível nos domínios próprios de cada civilização. Não poucas vêzes a ciência da literatura tem 
recorrido a êsse expediente explicativo do choque fronteiriço árabecristão.

O poema de Garrett filia-se nessa linhagem do fantástico luso-árabe e hispano-árabe. Ora a coragem para êsse fingimento de fantasias num poema histórico, para êsse revestir de um argumento romanesco em magias, provir-lhe-ia não só da visão romântica da Idade Média, como a difundira Walter Scott - autor por êle constantemente aludido - mas também do próprio Shakespeare, cujo teatro é um viveiro dêsses recursos ao mundo maravilhoso. Da freqüente presença dos Ghosts extraía a aparição do espectro de D. Manuel I em Camões; e do mundo de fadas e encantamentos feiticeiros, principalmente de The Tempest e $A$ Midsummer - Night's Dream, extrairia o ânimo e o autorizado precedente para êsse recuo estético da mistura híbrida do histórico ou meio histórico e do fantástico, de $D$. Branca.

Garrett não confessou esta influência shakespeariana. coisa pouco agradável aos artistas a declaração das suas dívidas. Mas, numa carta de Novembro de 1824, dirigida a Duarte Lessa, amigo certo nos anos incertos do exílio, engasta uma dissertação sôbre $D$. Branca. Aí confessa o seu propósito polêmico, nacionalista e popularista, a respeito de mitologias como decorações literárias: "Porém, os povos, que hoje ocupamos o mundo civilizado e que sucedemos a êsses ilustradores e dominadores do globo, temos outra origem, outra religião, outros costumes, outra história, outros preconceitos e outras tradições. $O$ que eram os oráculos para os gregos são para nós as feitiçarias, as buenasdichas, as sortes e adivinhos; os agouros dos romanos são as nossas bruxarias; as ninfas, as náiades, as divindades de uns e outros são os nossos espíritos, os nossos gênios, fadas, mouras encantadas, etc., etc. Os seus sonhos misteriosos as nossas visões, suas sibilas as nossas benzedeiras, e as suas metamorfoses os nossos encantamentos, os seus superi e inferi os nossos espíritos bons e maus - e assim por diante" (V. Págs. 781-2 da ed. cit. $2 .^{\circ}$ vol.). Depois dêste paralelo, ocorre a pergunta: quem foi que em plena vigência do classicismo renascentista fêz esta troca de mitologias em obras que a geração romântica viria a tomar para modelos, quem senão Shakespeare?

Este conceito de recuo estético poderia fazer pensar que $D$. Branca, se bem que publicada depois de Camões, fôra composta anteriormente; mas a correspondência trocada então entre o autor e José Gomes Mon- 
teiro suprime tôdas as dúvidas: em carta de 27 de julho de 1824, declara o Camões já pronto para entrar na imprensa; e noutra de 19 de novembro dêsse ano é que dá por concluída a $D$. Branca. A diferença cronológica é pequena, mas derimente quanto era preciso. De fato, a adoção dêsse maravilhoso nacional e popular era uma rebeldia contra a visão clássica do mundo, portanto um real progresso no caminho da reforma. Como progresso foi o conceito de bruxa, expresso no Arco de Sant'Ana, de que já se falará. E Garrett não esqueceu mais êsse mundo de sílfides e fadas, mesmo fora dos seus trabalhos de recolha dos monumentos orais folclóricos. Nas Viagens na Minha Terra, ao retratar uma das irmãs Robinson, recorda: "Vista à lua, no meio do seu parque, volteiando por entre os raros exóticos que no curto verão inglês se expoem ao ar livre, fàcilmente se tomava pela bela soberana das fadas, realizando aquela preciosa visão de Shakespeare, Midsummer night's dream". (V. pág. 263 da ed. cit., $2^{\circ}$ vol.) E em Helena, também retratando outra protagonista: "Não era uma beleza romântica: pesa-me confessá-lo. Silfa de Walter Scott não era; fada de Shakespeare não podia ser. " (Ibidem, pág. 119).

Byron e Scott é que eram os mestres inglêses imediatos e constantes do Romantismo. A respeito do poema iniciador, Camões, êle o confessou a Duarte Lessa: “ .geralmente falando o estílo vae moldado ao de Byron e Scott (ainda não usado nem conhecido em Portugal) " (Pág. 779 do $2^{\circ}$ vol. da ed. cit.). Mas o romantismo implícito em Shakespeare estêve presente sempre em seu espírito, sobretudo aquela audaciosa interpenetração de mundo contraditórios, que fêz dizer a Júlio de Castilho:

Os gnomos, os heróis, a história, a fantasia, passam como em tropel nesta fugaz poesia

(Depois de uma leitura em Shakespeare, in O Eremitério, $1875)$.

E a propósito de tôdas estas fantasmagorias - que muitas vêzes expressam verdades mais verdadeiras que a realidade -, ocorre-me outro elemento da obra de Garrett, que é susceptível de uma articulação do mundo shakespeariano: aquela Bruxa de Gaya, do Arco de Sant'Ana. Shakespeare foi o grande revelador da beleza da feialdade, do horrível e do macabro. Deveria antes dizer o consagrador. Na história dos va- 
lores literários importa mais o triunfo na expressão do que a prioridade balbuciante das criações. Ao lado das magias amáveis, das boas fadas e das sílfides, de Ariel e de Caliban, o poeta apresenta-nos espectros e bruxas, espectros de gentes assassinadas e bruxas anunciadoras de malefícios ou tentadoras de almas fracas e ambiciosas. Esse mundo era já anterior a Shakespeare. Quem se não lembra das bruxas do nosso Gil Vicente? Bruxas que eram apenas uma aristocracia da côrte de el-rei Diabo. E o Diabo é uma antiquíssima personagem literária, porque é também um velho companheiro dos homens. Não falta matéria à especialidade histórica designada por "demonologia". Tive em tempos o gôsto de estimular a compilação de muitas notas sôbre o senhor Diabo e de promover a publicação delas. Foi a monogratia da erudita investigadora italiana, D. Anita Seppilli, $O$ Diabo na literatura e na arte (In Revista do Arquivo Municipal, São Paulo, 1942, vol. LXXXV, pags. 7-122, trad. port.). Mas a entrada das bruxas no teatro shakespeareano foi uma consagração e já uma renovação, porque essas sacerdotisas do culto demonaco estão ali ao serviço da visão realista e supra-realista da vida. No tempo de Shakespeare tôda a gente cria em espectros e bruxas, menos êle. $O$ poeta incorporava-os entre as personagens das suas peças, porque êsses espectros e essas bruxas estavam presentes na consciência de todos e no convívio social. Era uma fidelidade realista, que as trazia à cena - como nos esboços vicentinos. A credulidade chegara a tal ponto que Jaime I, soberano contemporâneo de Shakespeare e homem de sólida cultura, pegou da pena e escreveu contra a influência da feitiçaria. Fê-lo com um tratado clássico: Daemonologia, de 1599, reimpresso em 1516. Aí denunciava a feitiçaria e exortava o poder civil a tomar as mais severas medidas de repressão. Assim transfigurado, êsse mundo fantasmagórico chega ao Romantismo e torna-se adôrno da longínqua e irracional Idade Média - onde tudo fôra possível. No tempo de Garrett, depois do século das luzes e da coroação da deusa Razão, ninguém cria em espectros, duendes e bruxas. Ocultismo e racionalismo eram inconciliáveis na mente emancipada. Essas coisas eram agora pitorescos acessórios da ação, situada em tempos de medos bárbaros. Os espectros passa a ser criações mórbidas de consciências sem govêrno da vontade e da razão; e as bruxas são imaginações do povo ignaro com que ele designa ou excomunga mulheres de procedência suspeita, caidas em miséria extrema, de passos misteriosos e costumes aberrantes da rotina 
coletiva. E essa procedência suspeita, êssa miséria extrema e êsses passos misteriosos, tôda êssa excentridade marginal tinha uma explicação única: uma grande desgraça de amor, uma sedução, um abandono cruel, um pecado a expiar. Às vêzes o filho dêsse fatal amor é que vem a ser o agente da vingança e da reparação. E a mulher, que se precipitara em miséria tão feia e desesperada que se tornara bruxa no consenso popular, ergue-se de novo à beleza e à virtude, e reentra no convívio normal. As grandes transfigurações morais, pela via do amor, eram freqüentes no teatro e na novela do Romantismo. E freqüentes são também essas bruxas temporárias por aclamação popular. Em Garrett, no seu Arco de Sant'Ana, há, uma, a Bruxa de Gaya, vítima da luxúria de um bispo odioso e violento. Vasco, filho de ambos, é o chefe de uma revolta popular contra a autoridade do sátiro e o agente da reparação à falsa bruxa. Esta desgraçada tem ascendência shakespereana, como tôdas as bruxas do Romantismo - ascendência distante, cuja genealogia não é possível reconstituir totalmente.

No Hamlet e não só no Hamlet, há um expediente expressivo ou de composição, que passou a Garrett, se não na sua integridade, ao menos num seu elemento principal: a representação de teatro dentro do teatro e a intervenção no argumento dêsse teatro de segundo plano, por alguma personagem do primeiro. Todos se lembram de que na tragédia shakespeareana Hamlet encomenda a uma companhia de atores ambulantes a representação de The Murder of Gonzago, em que se reproduz a cena do assassínio do rei, e escreve, para serem intercalados na peça, alguns versos repassados de intenção que põem à prova a resistência moral do tio criminoso.

E nessa ocasião, ao entregar o seu texto ao chefe da companhia, que Hamlet faz recomendações, de alto gôsto e sentido crítico, recomendações que articulam a obra àquele sub-gênero literário da "crítica poética", de que falei largamente em Pyrene.

Pois êste mesmo artifício de composição literária encontramos em Garrett, no drama histórico de início da reforma do teatro, Um auto de Gi1 Vicente, 1837. Barreto Feio e José Gomes Monteiro haviam chamado a atenção para o esquecido poeta dramático do século XVI, por meio da reprodução da edição de 1562, fundada no exemplar único achado na biblioteca da Universidade de Göttingue. Querendo associar o poeta das Barcas, fundador do nosso teatro, às suas diligências de restau- 
ração dêsse teatro, de acôrdo com o gôsto romântico, muito dado ao teatro e muito incapaz de fazer bom teatro, Garrett não podia esquecer o papel dos autos na vida cortesã do século XVI, nos seus saraus, e a atmosfera de heróica ufania que nestes saraus se respirava. Como disse um articulista da época, a peça de Garrett gira em tôrno de um acontecimento histórico, o casamento da Infanta D. Beatriz com o Duque de Sabóia e a sua partida para a côrte do marido, sucesso acêrca do qual temos notícias históricas positivas, sendo uma delas a representação das Côrtes de Júpiter, de Gil Vicente: "Há uma grande função na côrte, de que Garcia de Rezende nos conservou os mais minuciosos detalhes. Existe ainda o próprio auto que Gil Vicente compôs para as ditas festas e que foi representado no paço em plena côrte. Esse auto velho faz realmente todo o entrecho da peça moderna." (Pág. 632 da ed. cit., 1. ${ }^{\circ}$ vol.) Tudo isto nos leva a perguntar se a composição dramática, embrechada de teatro em teatro, não se ofereceria já feita a Garrett. Não era possível fazer aparecer Gil Vicente em cena senão como autor e ator numa própria peça, querendo guardar-se-lhe o verdadeiro e flagrante caráter. $O$ precedente de Shakespeare daria ânimo ao poeta português. Mas o que é inegàvelmente shakespeariano é a intervenção de Bernardim Ribeiro, uma das personagens da peça de Garrett, no próprio argumento vicentino: como Hamlet faz que um The Murder of Gonzago se recitem versos seus intencionais para desmascarar o padrasto, assim Bernardim Ribeiro à última hora se substitui a Joana do Taco no papel de Moura, para em vez de entregar, à Infanta em meio de uma geringonça galáicoandaluza, os presentes de Júpiter, um anel de condão, um dedal e o ter.çado de Roldão, lhe recitar vibrantes versos seus e lhe restituir um anel de esponsais, impossiveís esponsais, tudo isso, ali na presença do rei, do procurador do noivo e sua comitiva, e de tôda a côrte.

Esta peça vicentina é uma tranposição herói-cômica dos concílios dos deuses das velhas epopéias clássicas. Quando já os portugueses dominavam a navegação oceânica nos dois hemisférios, os deuses reunem-se para assegurar a pequena viagem da Infanta "por essas mares de Troia"! Isto contrasta flagrantemente a ufania do rei e de tôda a côrte - um ambiente heróico empequenecendo-se em versos chistosos e lisonjarias palacianas. Mas a ênfase passional de Bernardim Ribeiro, no enxêrto Garrettiano, restitui-lhe seriedade e viva emoção-emoção oculta, mas profunda, como a de Hamlet e dos amigos que estão no segrêdo da alteração 
do texto. E o auge do interêsse dramático de tôda a peça. Liquidada a situação sentimental entre a infanta e o poeta, nada mais interessa ao público; e o ato terceiro é uma excrescência estética, chega mesmo a prejudicar o ousado expediente de Bernardim. Se ainda voltavam a ver-se, para quê tanto risco de escândalo com a alteração do texto vicentino? Neste caso sucedeu como nos outros: a originalidade é de Shakespeare, quando põe um filho amargurado à espreita das reações do rei e padrasto diante da reconstituição do seu crime; mas a situação sentimental ampliase na peça romântica portuguêsa, quando um simples poeta ousa afrontar todos os riscos para dizer adeus à sua amada, que é uma princesa em partida para seus estados, filha do orgulhoso rei de domínios novamente descobertos por tôda a Terra. A emoção está não tanto na audácia, mas no contraste entre os direitos e atrevimentos da paixão e a hierarquia e os prestígios heróicos. E um contraste bem romântico. Assim o expediente dramático de Shakespeare perde em humanidade singular sem tempo, mas ganha em significado social, torna-se romântico, tìpicamente romântico e associa-se a uma grande época histórica. Verdade, verdade, também se poderá dizer que se reduz a ouropel decorativo do cenário de uma época histórica vista com superficial empáfia.

Quando, porém, Garrett chega às alturas do Fr. Luís de Sousa, reaproxima-se de Shakespeare, da medula do seu teatro, já não dos seus expedientes de composição, sim do seu espírito. Este drama garrettiano não é um drama ortodòxamente romântico, é uma tragédia; mas também não é uma tragédia, clássica porque é uma tragédia shakesperiana. Falta-lhe o espírito poético do teatro de Shakespeare, talvez porque o autor português, ainda que na plenitude da sua imaginação e da sua sensibilidade amorosa, como demonstrou pouco depois com as suas Folhas Caídas, sacrificou essas fugas líricas e filosóficas, tanto do gôsto de Shakespeare, à preocupação da documentação ou decoração local e temporal. Queria fazer uma peça de certa época, bem identificável.

Mas a concentração da sua fôrça emotiva, a sobriedade de sua composição de uma economia perfeita restituiram-no de algum modo ao verdadeiro sentido trágico dos antigos, tal como Shakespeare o humanizara. E essa condensação de fôrça trágica atinge o seu "climax" na cena final do ato segundo: 
"Jorge - Romeiro, romeiro! quem és tu?

Romeiro - (Apontando com o bordão para o retrato de $D$. João de Portugal) - Ninguém".

Todos os críticos louvam o poder de condensação da fôrça trágica do teatro de Shakespeare em exclamações universais ou monossilábicas. Aqui está um bom exemplo e em contradição franca do espírito retórico do romantismo. De resto, Garrett, quem sabe se por influência do próprio Shakespeare, foi em Portugal, ao mesmo tempo, o iniciador do romantismo, o exemplificador dos exageros do romantismo e o precursor da reação do gôsto contra o próprio romantismo. A maior parte do teatro garrettiano exemplifica as fraquezas do teatro romântico; e a sua Helena inacabada mostra que êle ia cair no romance de segunda mão; e vários passos das Viagens de minha terra confessam certo cansaço ou tédio da estética do Romantismo, que se ia tornando em estilo de escola. Este "ninguém" é o vertice de um cone de convergência de tôdas as ansiedades e presunções, incertezas e medrosas expectativas, e ainda das adivir.haçōes mórbidas da filha, Maria de Noronha, de tôda a atmosfera dolorosa que enche os atos anteriores. Mas êsse ambiente pesado de trágicos bulcões, a correr para um desfêcho doloroso, está purificado no realismo brutal do mundo shakesperiano. O romeiro, corroído de ciúmes, contenta-se com destruir um lar venturoso. E Telmo Pais não é nenhum lago que lhe remexa a ferida, lembrando maldosamente a formação do animal de dues costas, "the beast with two backs".

Sôbre esta cena empolgante do Fr. Luís de Sousa compôs uma tela o pintor Miguel Ângelo Lupi (1826-1883), quando pensionista em Roma, entre 1860 e 1863, à qual denominou $D$. João de Portugal. Lupi era retratista e num retrato aprumado de cavaleiro em hábito de monge transformou o que era um violento choque moral entre as três almas, choque produzido pelo aparecimento da rúna do que fôra D. João de Portugal, mas que de direito, pela situação do seu lar, e de fato, pela sua decrepitude, já não era "ninguém". O "aspecto severo e tremendo", recommendado na rubrica do autor, não suprimia num instante os estragos de "vinte anos de cativeiro e miséria, de saudades, de ânsias". A essência shakesperiana do episódio evolou-se, ao ser transposta do drama de Garrett para a tela de Lupi. Falta-lhe profundidade interior, assim perspectiva como emocional. Tem muito mais essência shakesperiana, por- 
que tem alta dignidade humana, certo monossílabo sôlto pelo rei $\mathrm{D}$. Pedro $\mathrm{V}$, de Portugal, numa carta particular sôbre a triste coisa pública. Júlio de Vilhena pô-lo em relêvo (8).

Não importa que Sousa Viterbo, na monografia documentar, que dedicou aos protagonistas do drama, se cansasse a apontar "ninguens" no teatro vicentino ( $V$ Memorias da Academia Real das Ciências. Parte I, tomo IX, Lisboa, 1902). A concentração dramática e a integração cênica dêsse "ninguém" são de Garrett, que de Shakespeare haverá tomado a coragem para fazer frente à declamação romântica.

Alguns panegiristas de Garrett encontraram linhas de beleza shakesperiana - portanto de fôrça de caráter e de humanidade - no tipo de Telmo Pais, criado pelo próprio Garrett, como ator na estréia do drama. Leio e releio a obra, rememoro as suas grandes interpretações cênicas, a que assisti durante muitos anos - e não lhe encontro nada de shakespeariano, se não lhe quiser descortinar algum mau sangue iago um iago senil, cuja velhacaria sagáz se transpusesse em sebastianismo evasivo e reticente, mas sempre com algum conteúdo de traição para os seus novos senhores, porque lhes envenena, dia a dia, a filha única e bem amada, com quimeras e suspeitas letais. Mas isto é muito pouco e muito indireto.

Não faltam no teatro shakespeariano mordomos e escudeiros, amas e áias, íntimos dos protagonistas, seus confidentes, conselheiros e colaboradores (V. Irvine, Dictionary of Shakespearean Names). E antes, na comédia antiga e na italiana, da Renascença, que a imitava, também não faltavam os escravos pedagogos, confidentes dos filhos-familia e cúmplices cáas suas extravagâncias e tropelias. Também nos costumes familiares portuguêses êsses escudeiros não faltavam, com sua função mista, meio servil e meio aparentada. Mas êste do Fr. Luís de Souza é bem português, bem romântico e bem garrettiano - ao que me parece.

O que por ventura se poderá ver em Telmo Pais será um adminículo caracterizador para adensar a tal côr local que o espírito histórico dos românticos buscava. Está ali como está o camonianismo da atmosfera, em dose maior que a do sebastianismo: Telmo Pais fôra amigo de Camões; D. Madalena de Vilhena lia familiarmente os Lusíadas; Maria de Noronha sonhava com o poeta; e um grande retrato dêle figurava entre os dos varões ilustres da casa Portugal. Nos começos do século XVII, Camões e a valorização da poesia tinham ainda de percorrer muito 
caminho para chegar àquela altura, que é de pleno século XIX. E aqui vinha a talho de foice recordar outra vez como é impreciso o historicismo de Shakespeare, que no acêrvo de temas emocionais da história procurava o eterno do homem, e como é intencional e escrupulosamente arqueológico o historicismo dos românticos em sua mira ao relativo e circunstancial. Pertencem a que época pertençam ou seja qual fôr a moldura histórica, de que desprendam, as personagens das tragédias e comédias de Shakespeare são coetâneas umas das outras, porque formam um só mundo - o mundo moral de Shakespeare, a sua visão total do homem. Têm a mesma unidade e simultaneidade cronológica dos habitantes do planeta de Balzac. Hamlet, episódio articulado ao século XI, expressa angústias intelectuais do mundo da Renascença, isto é, do mundo de Shakespeare. Ao contrário, a gente, que povoa o mundo dramático e novélesco dos românticos, ordena-se em vagas históricas ou cronológicas ou em gerações, cujas peculiaridades relativas e singulares êles procuram discriminar. Parentesco e unidade de sangue só a têm a dentro dos êrros psicológicos da escola, da sua concepção panerótica e do próprio temperamento de cada autor. Não é um paradouxo afirmar que o historicismo dos românticos falsificava a história. Nas Viagens na Minha Terra, do período áureo de Fr. Luís de Sousa, é que se encontra o melhor quadro da devoção garrettiana por Shakespeare. E a página de que os artistas Manuel de Macedo e Roque Gameiro extrairam a sugestão para uma das gravuras da edição de 1904. Sòmente, tiveram a infelicidade de preferir para a legenda a posição dos pés do poeta - "à noite com os pés no fender" - em vez das meditações ou leituras saboriadas pela sua cabeça. E estas eram confessadamente shakesperianas. Louva o escritor o prazer da leitura das grandes obras literárias no ambiente em que lhes decorre a ação ou em que o seu autor as concebeu. E exemplifica-o com as leituras de Tito Lívio e Horácio em Roma, com a da Crônica de El-Rei D. Fernando,"de Duarte Nunes de Leão, em Santarém, por onde anda no momento, com a de Shakespeare em Warwick e com a das Cartas de Abelardo e Heloisa em Paris, no Père-La-Chaise. E sôbre o trágico inglês confessa: “ Nunca tinha entendido Shakespeare enquanto o não li em Warwick ao pé do Avon, debaixo de um carvalho secular, à luz daquêle sol baço e branco do nublado céu de Albion. ou à noite com os pés no fender, a chaleira a ferver no fogão, e sôbre a banca o cristal antigo de um bom copo lapidado a luzir-me alam- 
breado com os doces e perfumados resplendores do old sack, enquanto o fogão e os ponderosos castiçais de cobre brunido projetam no antigo teto almofadado, nos pardos compartimentos de carvalho que forram o aposento, aquelas fortes sombras vacilantes de que as velhas fazem visões e almas do outro mundo, de que os poetas - poetas como Shakespeare - fazem sombras de Banquo, bruxas de Macbeth, e até a rotunda pansa e o arrastante espadagão do meu particular amigo Sir John Falstaff, o inventor das legítimas conseqüências, o fundador da grande escola dos restauradores caturras, dos poltrões pugnazes que salvam a pátria de parola e que ninguem os atura em tendo as costas quentes".

Neste breve quadro do confôrto de um serão inglês e do encanto das leituras feitas no cenário da matéria delas, quadro a que não falta sequer a evocação do old sack, "a bebida espirituosa celebrada por Shakespeare" (Pág. 276 da ed. cit., $2^{\circ}$ vol.) há uma distinção sutil, que encerra uma grande verdade crítica, entrevista pela intuição de Garrett, mas ainda não conquistada por certa crítica moderna, de caráter jornalístico pela improvisação impressionista. Garrett declara que entende melhor em Santarém a Duarte Nunes de Leão, que é um historiador de coisas passadas em Santarém, mas entende melhor a Shakespeare, que é um artista, lendo-o em sua própria terra e não nos cenários dos argumentos das suas obras dramáticas; não precisa de ir à Dinamarca para entender Hamlet, nem a Itália para entender Romeu e Julieta. Esta distinção é certeira. A obra de um artista revela sobretudo o espírito próprio artista; a realidade que ela nos oferece é uma interpretação sua, uma forma própria de ver e compreender. Redondamente se enganam os que pretendam entender a história inglêsa nas tragédias shakespearianas de matéria inglêsa, enganar-se-ão tanto quanto se enganam os que aprendem a vida portuguêsa do fim do século XIX nos romances de Eça. de Queiroz. Contra êste equívoco já fiz a minha advertência ( $V$ “. . Um pobre homem de Póvoa de Vartim. ", Lisboa, 1945 ou I apêndice da História da Literatura Realista, ed. de São Paulo, 1946).

A referência ao cld sack, também shakespearianamente saboreado por Garrett em Stratford-upon-Avon, merece aclaração. $O$ poeta português em nota identifica-o como sendo "boa e velha aguardente de França" e, um século depois, um professor brasileiro identifica-o também como bebida exótica, mas de Espanha. O Dr. Almeida Junior estudou profundamente a matéria na sua monografia. A embriaguez no teatro 


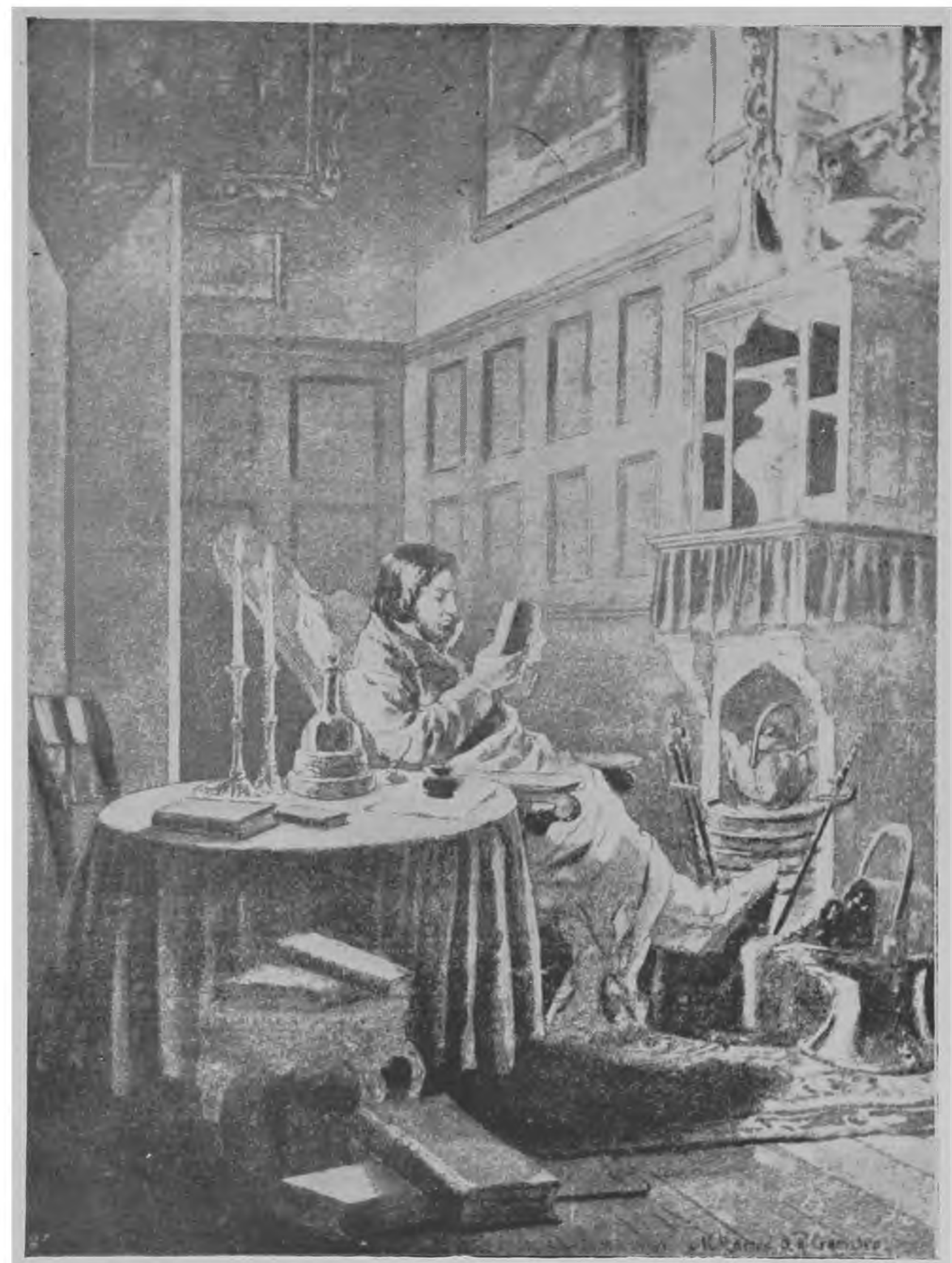

GAMLITTT 1.LNDO SHAKESPEARE AO SERÃO, LM WARWICK.

(Gravura das Oloras Completas de Almeida Garrett, edição de Lisboa, 1904, jlustrada por Mianuel de Macedo e Rouue Gameiro. Reprorl. do ling." Jorge Fideino de Figueiredo.) 
- 
de Shakespeare (in Revista da Faculdade de Direito da Universidade de São Paulo, vol. XXXV, fasc ${ }^{\circ}$. $1^{\circ}$ págs. 97-164, 1939). Aí encontro êste passo esclarecedor: "Os ingleses não fabricavam vinho; à tentativa da Idade Média, no sul do país, faltára continuação. Todo o vinho bebido no tempo de Shakespeare e nas suas peças teatrais, procede do estrangeiro.

O vinho mais freqüente é o "sack", isto é, o vinho espanhol. "Sack", diz um comentador do poeta, "era o nome dado a todos os vinhos espanhois, os quais, em regra secos e ásperos, requeriam fôssem abrandados com açúcar, a fim de atenderem ao paladar da época (Irving e Marshall, The Works of Shakespeare, 1888, págs. 392-3). A etimologia de "sack" não é pacífica: para uns, a palavra vem de "sêco", adjectivo que alude ao tipo de vinho; para outros, vem de "saco", porque a princípio o vinho espanhol era guardado em sacos de couro. Falstaff consome o xerez, como "sack" predilecto" (pág. 19 de separata).

A pronúncia comum da palavra, com o a aberto, faz optar pela etimologia "sacto".

Nas Viagens na Minha Terra, pela variedade do seu conteúdo digressivo, é que se pode fazer boa colheita de reminiscência shakespeareanas, começando logo pelo prefácio da $2 a$. edição, aquêle monumento de vaidade do escritor. Citarei ainda a evocação do bobo Yorick, o que trouxe Hamlet ao colo, como êle tristemente lembra à vista da sua caveira, no cemitério, junto do coval aberto para o corpo de Ofélia: "Estou com o meu amigo Yorick, o ajuizadissimo bobo d'el-rei de Dinamarca, o que alguns anos depois resuscitou em Sterne com tão elegante pena, estou sim." (Pag. 175, 2..$^{\circ}$ vol. da ed. de 1904). Estes "alguns anos" formam um intervalo de mais de século e meio, pois os Sermons of Mr. York, de Laurence Sterne, são de $1760-1767$ e as Letters of Yorick to Eliza são ainda posteriores, de 1775.

Em prólogos e no texto de outras obras, repetidamente aparecem reminiscências de Shakespeare, como a atestar que fôra bem profundamente saboreado e que lhe andava sempre a bailar por entre as associações da memória. Até naquele fragmento de romance, Helena, cuja ação decorre no sertão brasileiro, uma personagem de relêvo no quadro, a Viscondessa de Itaé, não se separa do poeta a que chama "o meu Shakespeare" (V. pag. 126 da ed. cit., $2 .^{\circ}$ vol.). Sòmente a citação daquêle dístico famoso de Hamlet sôbre a pequenez da filosofia aparece três vê- 
zes (Pags. 136, 166 do vol. $1^{\circ}$ e 157 do $2^{\circ}$ vol. da ed. cit.) e por fim traduzido em nota, com lapidar fidelidade e singeleza:

Há mais coisas no céu, há mais na terra, Do que sonha a tua vã filosofia.

(Pag. 275, ed. cit., $2 .^{\circ}$ vol.)

Mas Garrett era um artista, não era um crítico. E se não é legítima a separação entre a criação e a crítica, é bem patente o predomínio de um dêsses pendores do espírito em cada posição extrema. As penetrantes observações de Oscar Wilde em The critic as artist poderão lançar alguma confusão em quem não vir no paradoxo um método de raciocínio esclarecedor, mas precisado de leitura profunda. Esse é também o caso da cópia da arte pela natureza, um exagêro à superfície e uma verdade nas entranhas do paradoxo.

Foi principalmente de artista a contribuição de Garrett, mas não deixou de alguma coisa fazer como crítico ou em atitude crítica do espírito. Foi êle que preparou a realização das conferências shakespearenas do escritor irlandês James Sheridan-Knowles (1784-1862), que por Lisboa passou no ano de 1845, a caminho ou de regresso da Ilha da Madeira. Êssas conferências formaram, a propósito de Shakespeare, um verdadeito curso acêrca da literatura dramática inglêsa. Da série sôbre Shakespeare foi êste o programa, tal como se divulgou na imprensa da época (9):

"1a. Leitura. - O gênio de Shakespeare. - Diversidade dos seus caracteres. - Conservação da individualidade. - Perspicacidade poética. - Identificação extraordinária. - Juízo da posteridade. -

2a. Leitura. - Efeito do drama. - Júlio César. - Hamlet. - Cena do ator Kean com Ofélia. - Causas por que desagradam algumas composições dramáticas. - Dogmas dos críticos. - Figuras de dicção monossilábica. - Bruto e Cassio. -

3a. Leitura. - Unidade de ação. - O Mercador de Veneza. - Climas. - Unidade de caracteres. - Ilusão do drama. - Teorias absurdas. - Carater misto das tragédias de Shakespeare. - Arrebatamento". 
A outra série versou a tragédia e outros poetas inglêses antigos e modernos, tais como Milton, Pope, Southey, Scott, Byron e Campbell. Uma das teses prediletas de Sheridan-Knowles, como espírito bem possuído dos novos direitos românticos, era a demonstração da impossibilidade do drama trágico, dentro das unidades de Aristóteles. A perspectiva histórica mostra-nos hoje coisa muito diversa. O teatro romântico só sobreviveu, quando renunciou à anarquia e se reaproximou da estrutura clássica, sujeita agora a uma adaptação nova à realidade da própria substância da arte dramática. $O$ próprio Garrett o exemplificaria com o seu drama Fr. Luís de Sousa.

O filho de James Sheridan-Knowles publicou, em 1873, numa tiragem limitadíssima - 25 exemplares! - as conferências pronunciadas por aquêle sôbre literatura dramática em Belfast, 1830, em Liverpool, 1848, e em Filadélfia, nos Estados Unidos. Nesse volume, Lectures on Dramatic Literature, figuram várias conferências de matéria shakespeariana e em coincidência dos seus títulos com os sumários das de Lisboa. Isto pôe verossimilhança na conjetura de que se encontrem ali as idéias expostas em Lisboa, 1845, na presença de Garrett, ainda que não haja ali a menor alusão à sua estada em Lisboa, como a não há na biografia escrita por seu filho (Life of Sheridan-Knowles, R. B. Knowles, Londres, 1872, em tiragem também de 25 exemplares!), nem na tese do Prof. Leslie H. Meeks, da Universidade de Indiana, 1933. O único rasto lusófilo da obra dêste fecundíssimo autor dramático do romantismo, amigo de Kean e seu grande fornecedor de originais, é um folheto de 1850 sôbre o clima e a meteorologia da Madeira, escrito por outrem, mas editado por êle. Seria um tributo de gratidão. Mais ausente está Lisboa do Journal of a voyage to Lisbon, de Henry Fielding.

Também não é possível reconstituir os ecos de tais conferências. Não posso procurá-los na imprensa da época. Tenho, porém, à mão, coisa que mais nos importa: a impressão que elas deixaram no espírito de Garrett, há muito convertido ao culto shakespeariano, mas sendo felíz com achar novas razões para a sua fé. Entre os seus autógrafos apareceu um que respeita a êste ciclo de conferências. Tigura no tomo $1^{\circ}$ das suas Obras Completas, Lisboa, 1904, e reza assim, na parte diretamente referente a Shakespeare: "Shakespeare, o grande fundador do teatro moderno, devia necessàriamente ser o ponto de partida das considerações, das observações e da doutrina que ouvimos. Schelegel não ex- 
pôs meihor, com mais entusiasmo e conviç̧ão, as belezas, a verdade, a filosofia de uma escola poética, que hoje é quase universalmente reconhecida e seguida. $O$ gênio criador de Shakespeare, a diversidade de seus caracteres, a facilidade e verdade com que o poeta se identifica com seus personagens a ponto de nos tornar a ficção mais natural do que a realidade, e de modo que bem podemos exclamar com Byron, ao comparar a história com a sua poesia: Truth is strange, stranger than fiction! - tudo isto nos fêz sentir Mr. Sheridan - Knowles na sua primeira leitura. A dicção era fluente e animada, simples ou poética, segundo cumpria pela variedade dos assuntos. Mas o que sobretudo admirámos mais, e mais nos satisfez, foi ouvir recitar os bem conhecidos exemplos dos vários autores que trouxe para comparar as suas teorias - principalmente de Shakespeare.

A segunda leitura foi continuação do mesmo assunto. Nunca ouvimos declamar coisa alguma com tanta perfeição como as duas falas de Cássio e Marco Antônio na "morte de César". Nobreza, verdade, fôrça, tudo o que há de maravilhoso, de grande, de inimitável naquelas duas falas, sobressaía de um modo que não pode imaginar quem não tenha ouvido Talma - ou Mr. Knowles. Para cá do Reno não viveu outro homem em nossos dias, a quem o espírito de Melpômene se revelasse assim. Não falo dos absurdos desesperos, dos uivos e berros do drama, no sentido estrito da palavra moderna; falo da tragédia racional.

Mr. Knowles, discípulo e sacerdote de Shakespeare, não reconhece as unidades de Aritóteles; é protestante em Literatura. Muita gente é hoje dessa igreja; mas poucos aceitaram seus dogmas e discíplina com aquêle espírito de verdade e convicção, ou os sabem pregar com aquela persuação e eloqüência com que êle o faz.

$\mathrm{Na}$ terceira leitura, entre outras matérias conexas, veiu a questão das unidades: e com o exemplo de Macbeth - tragédia admirável que êle analisou rápida, mas profundamente - provou à evidência, demonstrou com tôda a severidade da lógica, sem perder das galas da eloqüência, que o verdadeiro drama trágico era impossível com as pretendidas três unidades de Aristóteles.

Shakesperare não se explica em três lições: mas bastariam decerto estas três lições para mostrar a qualquer que fôsse inteiramente hóspede na matéria, que sem um longo, profundo e meditado estudo da natureza — de que êle foi o primeiro intérprete - não é possível fazer coisa al- 
guma digna da arte, neste mais difícil de todos os gêneros de literatura, o dramático.

Shakespeare já fôra comparado a Eurípides; e com razão. Os ouvidos clássicos, a quem a proposição escandalizar, que vão ouvir $\mathrm{Mr}$. Sheridan-Knowles, e eu lhes prometo que hão de ficar convertidos." (V. págs. 495-6 das Obras Completas, $2 .^{\circ}$ vol).

Todo o conjunto da notícia lembra, pelo entusiasmo e pelo que reflete do próprio espírito do conferencista inglês, um artigo de crítico anônimo, escrito imediatamente depois de ter ouvido Liszt em Lisboa. Mais de cem anos depois ainda nos emociona a frescura da emoção recebida do músico pelo autor anônimo e do poeta que discorreu sôbre Shakespeare, pelo poea português. Como seríamos hoje mais ricos se dos grandes conferencistas do mundo guardássemos impressões assim diretas, frescas e vivas, em vez dos modernos relatos jornalísticos, impessoalmente noticiosos! A conferência é uma difícil forma da eloquência e participa da emoção lírica, da riqueza inteletual do ensáio e da viva representação histriônica. Não se compreende por que haja uma legião de críticos jornalísticos para o teatro e para a música, e não os haja para a eloquência universitária ou só se compreende pela banalidade, para que decaiu a conferência - para muitos apenas a leitura de papéis.

Gomes de Amorim, a propósito dêste comentário de Garrett às conferências de Sheridan - Knowles, escreve as linhas seguintes com notícia de contacto posterior entre os dois poetas: "Os artigos citados foram colecionados no tomo XXIV das Obras, onde se acha tambem o artiguinho que tem por título Mr. Sheridan-Knowles, dando notícia das seis leituras por êle feitas naquêle tempo em Lisboa, acêrca de Shakespeare. A 4 de maio de 1852 êste distinto literato escreveu a Garrett uma carta afetuosíssima, felicitando-o pela sua entrada no ministério, e recordandose com o mais vivo reconhecimento do modo por que João o acolhera e tratara em Portugal". (V. Memórias Biográficas, $3 .^{\circ}$ vol., Lisboa, 1884, pág. 135). Desta carta, enumerada no catálogo do Dr. Carlos Guimarães, genro de Garret, vem também mencionada no Inventário do Espólio Literário, por Ferreira Lima, à pág. 58, com esta rubrica: “25) Sheridan Knowles (James). Uma carta de 4-5-1852, com um apêndice autobiográfico".

Em 1886, Camilo Castelo Branco, no seu opúsculo já citado sôbre a tradução do Otelo pelo rei $\mathrm{D}$. Luís de Portugal, refere-se a um Sheri- 
dan e a um seu tipo, Joseph Surface (Pág. 38), mas êste Sheridan nada tem com o conferencista shakespeareano de 1843, em Lisboa; é Richard Brinsley Butler Sheridan (1751-1816). E Joseph Surface é um dos protagonistas da sua aplaudidíssima comédia, The School for Scandal, de 1777.

Havendo assinalado algumas presenças do mundo shakespeariano na obra de Garrett, chega o momento de reparar nalgumas ausências dêle. no Tratado de Educação, série de cartas dirigidas a $\mathbf{D}$. Leonor da Câmara, Marquesa de Ponta Delgada, incumbida da educaçãi da jovem rainha D. Maria II, o nome de Shakespeare não ocorre com o esperado relêvo em capítulo sôbre a educação literária, porque tal capítulo não existe; apenas é recordado num passo acêrca da aprendizagem das línguas por meio da leitura dos grandes monumentos literários: "Que inglês saberá o que não souber Addison, Shakespeare, Pope, Blaire?" (Pág. 295. ed. cit., $2 .^{\circ}$ vol.). Esta ausência quase total é reparável, mas é explicável: em 1829, data da publicação do Tratado de Educação, ainda se não havia criado o ensino regular das literaturas e menos ainda se havia reconhecido o seu grande papel formativo nos planos gerais de educação.

Outra ausência de Shakespeare se notará na estrutura do teatro de Garrett. Tendo bem viva e clara em seu espírito a revolução na arte de fazer teatro que o romantismo trazia, havendo oposto vêzes várias Shakespeare a Eurípedes e Racine, não deixando de aludir à querela crítica das unidades dramáticas, Garrett, que nos prefácios demonstrou uma elevada consciência crítica, não aproveitou o genial exemplo de Shakespeare, com suas peças decompostas em quadros mínimos, numa vertigem mecânica muito cinematografável, ao gôsto moderno; pelo contrário, sempre que pôde, nas suas peças principais tendeu para a unidade do lugar, pelo menos para a sua redução ou concentração dos cenários. Em Um auto de Gil Vicente a ação desdobra-se por três lugares, tantos quantos os atos: Cintra, Paço da Ribeira e o galeão de partida para Itália. Só no ato segundo é que há sua mutação de cenário, verdadeiramente uma interposição de, duas cenas na sala do trono, que aparece por detrás do pano do fundo. Não chega a ser mudança de lugar ou desacatamento da sua unidade. $\operatorname{Em} D$. Filipa de Vilhena, o argumento decorre em casa de Ruy Galvão e em casa de D. Filipa de Vilhena, três atos em dois lugares. Em $O$ Alfageme de Santarém os atos são cinco e 
- lugar é apenas um, a Ribeira de Santarém, em frente da casa do alfageme. E no Fr. Luís de Sousa, se há alguma variedade de lugares, tal variedade está compreendida nesta outra unidade: o ambiente caseiro de D. Madalena de Vilhena, uma dona do século XVI, que pouco saía de casa; e essa variação faz-se tôda em Almada e nas adjacências do mosteiro dos frades dominicanos. As suas grandes mutações da ação, o incêndio no fim do $1^{\circ}$ ato e a profissão dos esposos no fim do $3^{\circ}$, determinam variações mínimas dentro da mesma vila de Almada, de um palácio para outro, e dentro da mesma cena, só com o correr o pano do fundo. Isto significa um grande sentido da interiorização do drama, fôsse espontâneo, fôsse de influência clássica, e é um dos tais indícios de que no mesmo Garrett, iniciador do nosso romantismo, principia também a reação contra o romantismo. A sua devoção por Shakespeare não o impediu de se defender dêle, ainda que muito bem soubesse, com o exemplo do coevo teatro francês, quantas liberdades deambulatórias se poderia permitir um autor dramático. Em 1844, no prólogo á 1a. edição do Arco de Sant'Ana, já depois de representado o Fr. Luís de Sousa, alude a essa característica do drama inglês: "Deixá-lo, deixá-lo e transportemo-nos nós, amigo leitor, para mui diverso, posto que não mui apartado lugar. Façamos, com a rapidez com que em um teatro britânico se faz, a nossa mutação de cena; e deixar gemer as unidades de Aristoteles, que ninguem desta vez the acode" (Pág. 12 , ed. cit., $2^{\circ}$ vol.) Também se poderia estranhar a ausência de rubricas sôbre a indumentária dos atores no teatro de Garrett - de Garrett, homem sempre tão preocupado de efeitos impressivos que da sua comparência no parlamento fazia um ato de elegância histriônica. Isso estaria no seu gôsto e estava também na estrutura do teatro shakespeariano. Quando surgiu, muito mais tarde, a opinião favorável à indiferença pela indumentária dos atores, Oscar Wilde saiu a campo, com seu famoso ensáio, The truth of masks, em que restabelece a colaboração do vestuário na afirmação da personalidade e salienta quanto Shakespeare sabia essa verdade.

E é tudo que se me oferece dizer sôbre a presença e a ausência de Shakespeare em Garrett. E é bem pouco, mesmo com o risco de haver descido a miudezas. Não chega para se situar Garrett na evolução dos juízos e idéias sôbre Shakespeare. Verdade é que a selva dos problemas suscitados pela interpretação psicológica do teatro de Shakespeare e pela sua realização artística adensou-se principalmente depois de Garrett. $\mathrm{O}$ 
que seja a espessura dela mostrou-o recentemente o Prof. Luís Cardim num precioso voluminho, Os problemas do "Hamlet e as suas dificuldades cênicas, Lisboa, 1949, erudita recapitulação sugerida pelo "film" de Lawrence Olivier.

Com tudo isso não podemos medir a ação pessoal do poeta português, como homem do mundo e árbitro do gôsto, na difusão da estima pública pelo trágico inglês. $O$ episódio das conferências de SheridanKnowles entrará no campo dessa influência. Mas em que medida contribuiu a sua autoridade para o ambicioso projeto de uma tradução integral de Shakespeare, que Ramalho e Souza anunciou? E o entusiasmo de A. P. Lopes de Mendonça, crítico do romantismo, confessado nos folhetins da Revolução de Setembro, recopilados em 1849 nos Ensáios de Crítica e Literatura e refundidos em 1855 nas Memórias de Literatura Contemporânea, que deveu êle a Garrett, a par do que deveu à crítica francesa?

Podemos calcular o que a posição de Garrett perante Shakespeare significava em objetividade crítica, se lembrarmos a posição muito posteriormente assumida por Camilo Castelo Branco, pontífice do subjetivismo sentimental da nova burguesia entronizada pelo regime liberal. Escrevia o romancista em 1886 (!), a propósito de uma tradução do Otelo pelo rei D. Luís I, de Portugal: "Nem a apoteose métrica entoa-* da por Victor Hugo, nem a prosa de Taine, esmiuçadora até ao fastio, me fariam, perceber melhor o que é incompreensível - a obra de Shakespeare, esse torvolinho de trevas e constelações, segmentos astrais, a desordem de um novo mundo moral no primeiro período da sua cosmogonia" (V. Esbôço de crítica, "Otelo ou o Mouro de Veneza", pág. 7.). O que "melhor" o ajudava a compreender êsse "incompreensivel teatro era o poemeto de Júlio Castilho, já citado, Depois de uma leitura em Shakespeare. E a seguir glosa aquêles versos na mais heteróclita das enumerações. Perante o realismo crú do teatro shakespeariano o gôsto de $\mathrm{Ca}$ milo e a sua psicologia, que tudo articulava ao sentimento e à imaginação, guardavam uma desagradada reserva, semelhante à que o divorciou do romance realista do século XIX. E êsse realismo também remontava a Shakespeare, por uma das suas direções, a mais liberta de ouropéis fisiológicos. Tôdas as escolas ou frases da expressão literária estão implícitas na obra de um grande gênio, cujo conteúdo se vai decompondo sob a ação do meio ledor. 
Em Garrett havia também um forte espírito burguês de acomodação e decência ou conveniência, que lhe detém o desenvolvimento pleno de alguns germes que se ostentam em sua obra. Era romântico e considerava o Romantismo obra inglêsa (V. pág. 487, Obras, ed. de 1904, $2^{\circ}$ vol.); e, como romântico, sofria do prejuízo da superioridade incontestável de Lord Byron: "Realmente o século estava muito atrazado: Milton não se tinha ainda sentado no lugar de Homero, Shakespeare no de Eurípides, e Lord Byron acima de todos. " (Ibdem, pág. 164). Mesmo descontando algum humorismo no dizer, entrevejo aqui uma ordenação de valores prejudicial à plena compreensão de Shakespeare. Mag sempre demonstrou uma elevada sinceridade estética e crítica. E foi essa boa fé intelectual, aliada à espontânea neofilia do seu liberalismo, que o fêz recolher nos seus exílios inglêses as três coisas grandes, que a Grã-Bretanha de então lhe podia ensinar ou revelar: Shakespeare, o Romantismo e o exercício da liberdade (10). A política reacionária de Jorge IV era mais para uso externo. Garrett viu ali bem mais do que viram em Portugal alguns viajantes inglêses seus contemporâneos, que preferiram encantar-se com o primitivismo pitoresco do povo humilde e não tiveram olhos para os valores principais (11). Viram muito pouco, mesmo guardadas as proporções entre as fôrças criadoras dos dois povos naquela sasão. Para achar curiosidade e justiça para êsses valores principais será necessario subir a zona mais alta, à dos historiadores dos descobrimentos e da formação do império inglês, e à das repercussões camonianas - estas já apontadas com sólida erudição pelos professôres Féliz Walter, do Canadá, George West, da Grã-Bretanha, e Luís Cardim, de Portugal (12). Torno a reconhecer: tudo isto é coisa pouca. Mas sempre ofereceu o ensejo para uma excursão pelo universo shakespeariano e faz sentir ainda uma vez o magnetismo de uma personalidade como a de Garrett.

Para os leitores brasileiros estas notícias não carecerão de algum interêsse, porque o poeta do Camões, e também o prosador das Viagens na Minha Terra, foi uma das grandes influências em sua cultura literária, no século XIX. José Veríssimo, Arturo Farinelli e H. de C. Ferreira Lima documentadamente o mostraram, e um jovem universitário, Carlos de Assís Pereira, o relembrou recentemente.

E não se creia que o estudo da carreira de uma grande obra de arte, através da alma de um povo e ao longo dos séculos, seja coisa de cus- 
cuvilhice histórica, sedenta de pitorescas anedotas. Muito ao contrário: êste capítulo da literatura comparada recompõe-nos a biografia das grandes obras, mostra-nos o seu crescimento e o do meio, que as entende ou não entende, mas por sua cooperação interpretativa, pouco a pouco thes vai esgaravatando no contéudo opulento. E como seguir um cone de luz, que parte de um foco imortal - a obra, como saiu da inspiração do poeta - e acompanhar a luta dêsse feixe com os obstáculos do caminho e logo reconstituir a essência verdadeira da obra ou chegar de novo à luz pura e livre. Uma grande obra de arte é uma vivência autônoma, que para sempre se aparta do seu criador e da sua moldura social, para construir sua biografia, correr suas aventuras e cumprir seu destino. E êste viver próprio da obra de arte importa-nos, a todos, muito mais que a biografia do autor, o quadro social, a bibliografia e tudo que a história literária do século XIX acumulava em tôrno dela.

A gênese e o destino de uma grande obra de arte poderiam ser perfigurados num pequeno esquema: dois ângulos verticalmente opostos. Um expressaria a convergência das fôrças condensadas e elaboradas na criação do poeta; o outro traduziria a marcha da criação nova para o futuro, com potencialidades multiplicadas, como nos focos das lentes. A história literária do século XIX estudou profundamente o campo do primeiro ângulo; a do século $\mathrm{XX}$ deverá aplicar-se ao segundo ângulo, ao campo imediato à criação, portanto a todos os problemas implícitos na vida livre das grandes obras, as suas permutas com os meios sucessivos, as suas perspectivas desfiguradoras ou enriquecedoras, os acertos e os êrros dêsses meios na avaliação delas, os seus ensinamentos para a melhor compreensão do homem pelo homem. Shakespeare é tão grande que até a mais intransigente crítica partidária reconhece nêle um marco miliário na libertação do homem.

São Paulo, Junho de 1949.

$$
N O T \text { A S }
$$

(1) Ler-se-á com todo o proveito o estudo do Prof. René Wellek, The concept of "Romanticism" in Literary Hislory, em publicaçāo na nova revista Comparative Literature, Eugene, Oregon, Estados Unidos.

(2) V. A Épica Portuguêsa no século XVI, Madrid, 1930, várias vezes reimpressa e refundida para nova edição próxima.

(3) V. H. de C. Ferreira Lima, Inventário do espólio literário de Garrett, Coimbra, 1948, 107, págs. Este inventário só agora foi feito,. 
porque também só quase um seculo depois la morte do poela os seus papéis saíram de mâo de um particular para serem incorporados numa biblioteca pública, mediante aquisição pelo Estado. Durante a revisão dêste pequeno estudo, chegoul-me a notícia da morte do Coronel Henrique de Campos Ferreira Jima, a maior autoridade nos estudos garrettianos. Aqui registro o meu desgôsto pela perda de tão bom amigo e a minha graidāo pela solidariedade que sempre lhe devia, na minha carreira literária e em várias situaçốes nada litterárias.

(4) Este passo do prólogo da $1 .^{\text {a }}$ edição da tragèdia Catão retifica as linhas seguintes do Prof. René Wellek, à pág. 1.2 de Comparative Literature, que enccrram uma pequona inexatidão: "Among Porluguese poets, Almeida Garrett seems to have been the first to refer to "nos romanticos" in his poem, Camoens, written in 1823 in Le Havre during his French exile" O Prof. Wellek fundou-se em Th. Braga, Historia do Romantismo em Portugal, Lisboa, 1880, pag. 175.

(5) V. o meu ensáio $A$ mulher de Garrelt, in Torre de Babel, Lisboa, 1924.

(6) V. o meu ensáio Donjuanismo e anti-donjuanismo em Portugal. in Críticas do exílio, Lisboa, 1930.

(7) $O$ critico argeniino D. Calisto Oyuela assinalou de modo certeiro csse risco, e precisamente a propósito de Shakespeare, que Tamayo Y Baus levou á cena, como personagem de l'n Drama Nuevo, V. Esindios Literarios, 2. ${ }^{\circ}$ vol., Buenos Aires, 1943, pág. 183.

(8) A propósiio da condensaçāo do máximo éfeito expressivo de alguma grande emoção, que ultrapassa os recursos da retórica, ocorremme o comentário de Júlio de Vilhena a certa exclamação monossilábica do Rei D. Pedro V, de Portugal, comentário certeiro, a que só falta a menção do nome de Shakespeare, mestre desse tipo de? sublime. V. D. Pedro $V$ e seu reinado, $20^{\circ}$ vol. págs. IX-X Coimora, 1921 - 1922.

(9) Mencionei êste episódio, com algumas ouiras noticias sôbre o reconhecimento de Shaliespearc em Portugal, às págs. 88-89 da 1.a ed. da minha História da Crítica Litterária em Portugal (Da Renasrença á Atualidade), Lisboa, 1910, mas na $2 .^{a}$ ed., inexplicàvelmente, suprimi coste passo. Pensaria iá então ern dedicar a matéria um ensáio independente? Acêrca de James Sheridan-Knowles prestou-me algumas informaçies o meu amigo, Prof. Charles B. Boxer, do King's College, de Londres, as quais vivamente agradeço.

(10) Sobre o esteticismo de Garreti encontrará o leitor algumas idéias na História da Literatura Romântica, Lisboa, 1913, cuja última edição é de 1946, São Paulo, Brasil, Livraria Anchieta. Os seus esforços doutrinários e ativos em prol da formação de uma verdadeira consciência cívica liberal é que não foram ainda estudados com detença e postos no relêvo, a que têm direito, lado a lado com os Opúsculos de Herculano. O nome de Garrett, como orador, publicista e jornalisia, pertence legitimamente à historia do estabelecimento do sistema representativo, tanto quanto à historia literária.

111) - V. a conferência de Alberto Candeias, Porlugal em alguns escritores inglêses, Lisboa, 1946.

(12) V. La Littérature Portugaise en Angleterre à l'époque romantique, Paris, 1927; Luiz de Camões e o romantismo inglês, 1938; e Projecâao de Camões nas letras inglesas, Lisboa, 1940. 